\title{
PRÁCTICAS DEL CONDE Y FORMACIÓN DEL FEUDALISMO. SIGLOS VIII A XI
}

\author{
CARlos Astarita \\ Universidad Nacional de La Plata \\ Universidad de Buenos Aires
}

\begin{abstract}
Resumen: Con documentación de distinta procedencia se elabora un modelo sobre evolución de las relaciones entre los condes y los campesinos en el área norte castellano leonesa, entre los siglos VIII y XI. El conde imponía rentas de manera gradual en base a una reformulación de antiguas costumbres, transformando relaciones de reciprocidad en relaciones de extracción de trabajo. Con este marco se estudia la documentación de Santa María de las Dueñas, donde se ve la acción condal, hacia el año mil, sujeta a principios similares a los que surgen del modelo general. El conde se sumergía en la lógica campesina adoptando una conducta calculada y constructiva, en tanto regulaba las relaciones entre las unidades de producción, pero al mismo tiempo modificaba la estructura absorbiendo propiedades e introduciendo vínculos de subordinación. Esta visión se acerca a la tesis de la mutación feudal al otorgar prioridad al poder político como medio de formación del señorío, pero se aleja de esta tesis al establecer que no se dio un cambio súbito y regionalmente sincrónico por violenta imposición ex nihilo de nuevas costumbres. Con estas prácticas, el conde se convertía en señor feudal.
\end{abstract}

Palabras claves: prácticas del conde -sociedad campesina- formación del feudalismo

Abstract: Based on documentation of various origins a model of the evolution of relationships between counts and peasants from the Northern Castillian-Leonese area was drawn up, covering the period from the $8^{\text {th }}$ century until the $11^{\text {th }}$ century. The count used to gradually levy a tax based on a restatement of old customs, transforming reciprocity relationships into relationships were peasants were divested of their work. The Santa María de las Dueñas documentation is studied according to this framework, where count actions are recorded toward the year one thousand, subject to similar principles to tho- 
se arising from the general model. The count usually immersed himself in the peasant logic by adopting a calculated and constructive behavior, while regulating relationships between production units, but at the same time modified the structure by taking over properties and introducing subordination ties. This view leans towards the feudal mutation thesis by giving priority to political power as a means to develop dominion, but it drifts apart from said thesis since it states that a sudden and regionally synchronous change caused by a violent ex nihilo imposition of new customs was inexistent. With these practices, the count became the feudal lord.

Keywords: practices of the counts - peasant society-formation of feudalism.

\section{INTRODUCCIÓN}

El proceso de formación del feudalismo en el reino asturleonés es una cuestión controvertida ${ }^{1}$. Para algunos medievalistas, a comienzos del siglo XI persistía todavía una sociedad antigua dominada por el tributo fiscal; otros (en realidad la mayoría) afirman que ya por entonces se había constituido plenamente el régimen señorial. El resultado es una cronología sobre el surgimiento del feudalismo muy desigual: desde el bajo imperio romano hasta el siglo XII, hay oportunidades para encontrar una génesis adaptable a cada propuesta.

Divergencias tan amplias reflejan, en último término, el problema de análisis de la relación social señor campesino, y con éste el de las prácticas de subordinación social. Es el tema de este estudio, referido a la actuación de los condes que construían el régimen feudal de producción transmutándose de autoridades públicas en señores feudales.

El punto de partida elegido nos sitúa en el campo del poder como herramienta de construcción de las relaciones sociales de producción, perspectiva que se conecta con la historiografía de la llamada mutación feudal. Para Pierre Bonnassie, autor del libro que inaugura esa línea de estudios, el cambio sobrevino en el espacio catalán en un tiempo corto, entre los años 1020 y 1060, a través de una violencia anárquica que sólo fue absorbida por diferentes procedimientos, y en particular por las relaciones de vasallaje ${ }^{2}$. Si una cuestión retiene la atención del lector, es el papel que en esa obra se adjudica a la práctica social. Alejado de un evolucionismo sociológico «natural», dado por modificaciones no conscientes de las fuerzas productivas o del parentesco, Bonnassie describe el dramático accionar violento de la nueva clase de poder. Es el problema que se revisará críticamente en este artículo.

\footnotetext{
1. La situación de los estudios en SALRACH, J. M., «Les feodalités mérdionales: des Alpes a la Galice», en BouRNAZEL, E y Poly, J-P., Les feodalités. Histoire générale des systèmes politiques, París 1998.

2. Bonnassie, P., La Catalogne du milieu du Xe a la fin du XIe siècle : croissance et mutations d'une société, Toulouse-le Mirail, 1975.
} 
Se tratará, en concreto, de establecer cómo actuaba un poder político que cumplía un papel estructurante del modo feudal de producción. La violencia era, según la hipótesis a demostrar, sólo una parte de un comportamiento social complejo y cuidadosamente elegido. Debemos introducirnos, pues, en uno de esos territorios en los que actuaban los condes. En este aspecto, los accidentes históricos permitieron que para León se conservara una documentación excepcional, el archivo de Santa María de Otero de las Dueñas, monasterio situado en el pueblo del mismo nombre, a treinta kilómetros de la capital, que permite conocer a dos condes, Froila Muñoz y Pedro Flaínez, en los alrededores del año mil $^{3}$. Su perfil sociopolítico y sus funciones no diferían de las que ostentaban otros jefes de distrito ${ }^{4}$.

El análisis micro social se situa inevitablemente en un contexto histórico. Para establecerlo, se formulará, con testimonios combinados, un modelo evolutivo de la praxis condal entre el siglo vIII y principios del XI. Este modelo, lejos de ser un marco descriptivo, nos introducirá en la lógica del control político sobre las unidades de residencia campesina. Dicho en otros términos, el esquema inicial permitirá encuadrar en un proceso general de formación del feudalismo el carácter socialmente constructivo de la autoridad y la coerción política que se manifiestan en el estudio local. El enunciado enfrenta de manera crítica a la tesis de una génesis súbita y espacialmente sincrónica del modo de producción feudal mediante el exclusivo recurso de la violencia.

3. Del Ser Quijano, G., Colección diplomática de Santa María de Otero de las Dueñas (León) (854-1037), Salamanca 1994, en adelante ( $O$ de las Dueñas). El estudio introductorio nos sitúa en el contexto del archivo.

4. O. de las Dueñas, doc. 30, «et deuenimus indem ad iudizio antem gomite Fllaino Munizii uel suos iudizes ic in Orete»; doc. 74, Pedro Flaínez, «comes, ad sua mandacione ad Lorma» y doc. 87. Los límites con otro condado, en, idem, doc. 53, en una delimitación de propiedad, «per terminu de gomite Frenando Didazi» (p.75). Las concesiones podían ser diversas. Fernández del Pozo, Alfonso V, rey de León. Colección diplomática, en, León y su historia. Miscelánea Histórica, León 1984, en adelante, Alfonso V, doc. 14, en el 1014, el rey daba la villa de Abacif a Pedro Fernández con el derecho de mando, y aclaraba que «hominis qui ibidem uenerint populandum lilcenciam (sic) tibi damus eis colligendi et tui sit incuntanter arbitrii iudicandi et regendi per suos antiquiores terminos». Serrano, L., Cartulario de San Millán de la Cogolla, Madrid 1930, en adelante, $M$. de la Cogolla, doc. 22, año 1040, se menciona «Enneco Lupez Viscayensis comes». HerRERO DE la Fuente, M., Colección diplomática del monasterio de Sahagún (857-1230) II (1000-1073), León 1988, en adelante, Sahagún II, doc. 534, año 1049, «comite Fredenando Monniz tenente Campo de Tauro et Zamora». SÁnchez Albornoz, C., «Alfonso III y el particularismo castellano», en Orígenes de la nación española. El reino de Asturias. Estudios críticos sobre la historia del reino de Asturias, Oviedo, 1975, p. 885 y s., hacia el año 865 Castilla estaba regida por cuatro magnates, en la parte mas vieja y Álava, en el alto Ebro, en la Bureba y en la zona de Burgos. En Galicia, idem, «La repoblación oficial», en Orígenes, p. 435, n. 37, año 910, «Nos omnes comites seu imperatores quanticumque sumus in comitatus obtinemus de iure per ripa maris usque in Lesute et de super per Navia superiore usque in Silie...». Sobre la cuestión en general, SÁnchez Albornoz, C., «Imperantes y potestates en el reino asturleonés (718-1037)», Cuadernos de Historia de España, XLV-XLVI, 1967. 


\section{SIGLOS VIII-XI. UN MODELO DE EVOLUCIÓN}

La reconstrucción del proceso y la racionalidad de la praxis condal comienzan a resolverse con una serie de testimonios de distintas cronologías y lugares. En su diversidad, expresan transformaciones territorialmente limitadas, con lo cual la totalidad sólo puede captarse por generalización.

El primer texto es el fuero de Brañosera (en Palencia) del año 824 (aunque hay dudas sobre su datación), dado por el conde Munio Núñez a cinco familias campesinas $^{5}$. Delimitaba un lugar de instalación, y establecía que el montazgo (tributo de pastos para los que acudieran de otras aldeas) se repartiera entre el conde y los pobladores. Pero además, eximía a los campesinos del servicio de vigilancia en el territorio o en el castillo, obligándolos en cambio al pago de tributo y renta ${ }^{6}$. El segundo texto es del año 971. El concejo de Agusyn (Los Ausines) se liberaba entonces de la construcción del castillo cediendo una dehesa al conde García Fernández ${ }^{7}$. Una tercera escritura son los fueros que Fernando I daba en el año 1039 a las villae de San Martín, Orbaneja y Villafría, exceptuando a sus moradores del trabajo de los castillos y de participar en la guerra ofensiva, y establecía que «serviant ad atrium Sanctorum Apostolorum Petri et Pauli ${ }^{8}$. En la zona de Zamora, con una evolución más tardía, encontramos otro texto. Se trata del fuero concedido por el conde Ramón de Borgoña al lugar de Valle en el año 1094. Entre otros deberes, liberaba a sus pobladores, de ir a la expedición militar, e imponía dos días de trabajo en las tierras condales ${ }^{9}$. Estos documentos, a los que se podrían agregar otros ${ }^{10}$, expresan una secuencia: el tránsito de obligaciones militares a rentas agrarias.

En base a estos elementos, podemos aventurar que en el período post visigodo, la expedición y la defensa militar serían cargas del conjunto de los pobladores. En cada territorio más o menos delimitado, la mandación, los campesinos bajo la jurisdicción de una autoridad política, el rey o los condes, se encargaban de la vigilancia, la reparación de las fortalezas y la guerra ofensiva. No es ésta una mera deducción de las exenciones antes señaladas. Del año 1025 conocemos

\footnotetext{
5. MuÑoz y Romero, T., Colección de Fueros Municipales y cartas-pueblas de Castilla, León, Corona de Aragón y Navarra, Madrid, 1847, p. 17

6. MuÑoz y Romero, op. cit., Fuero de Brañosera, p. 16-18, «Non dent anupda, non vigilias de Castellos nisi dent tributum et infurtione quantum poterint ad comite qui fuerit in Regno».

7. Serrano, L., Becerro Gótico de Cardeña, Valladolid 1910, (en adelante, Cardeña) p. 7, dice, «quod ingenuasti nos de illo labore de illos castellos» (p. 7).

8. Cardeña, doc. CCCLXX, p. 379, «nulla expeditione publica que dicitur fossato»

9. Rodríguez Fernández, J., Los fueros locales de la provincia de Zamora, Salamanca 1990, en adelante, Fueros locales de Zamora, doc. 4, tit. 4, 'Barones de Valle faciant illa serna de palacio II dies».

10. Muñoz y Romero, p. 49, año 978 y M. de la Cogolla, año 1002, p. 80.
} 
un juicio, presidido por Alfonso V, entre el obispo de Lugo y pobladores de los alrededores de Braga. Mientras que los clérigos sostenían que eran siervos, el representante de los pobladores defendía su condición de libres. Afirmaba que sus antepasados, emigrados desde Oviedo como ingenuos, tomaron tierras por presura y cumplieron el servicio de guerra (fonsado) para reyes y condes ${ }^{11}$. Es indiferente ahora considerar si apelaba a un mero argumento de circunstancias para liberarse de la condición servil en un juicio que termina por perder. Nos interesa que da cuenta de una prestación militar por parte de propietarios independientes, que se conecta con las obligaciones colectivas antes indicadas. En el marco de esa actividad surgían los condes al frente de castillos para la defensa y la coordinación de expediciones, como atestigua la Crónica albeldense ${ }^{12}$. Un texto dice de «Odoario digno bellatori», que, en el año 873, «uicos et castella erexit et ciuitates muniuit et uillas populauit $\rangle^{13}$. Este marco sería pues el de los primeros tiempos de la «Reconquista», y en él puede incluirse a Pelayo (primer rey de Asturias, 718-737), posiblemente un comes que habría roto un primitivo acuerdo transitorio con los musulmanes ${ }^{14}$.

La presencia de campesinos libres en las expediciones evoca a un estrato social amplio, no noble, difícil de caracterizar, que habría sido habitual en la organización germánica prefeudal ${ }^{15}$. La movilización general indica que el número de miembros del séquito estable del conde debía ser en un principio reducido, y la demanda de excedentes agrarios para alimentar ese pequeño vértice político militar debió ser

11. Alfonso $V$, doc. X, p. 248, «fecerunt fosato de rex nostros auolos et de comites».

12. Bonnaz, I., Chroniques asturiennes. (Fin IXe siècle), París 1987, Crónica de Albelda, 47,7; 47,9; 47,10.

13. López Ferreiro, A., Historia de la Santa A. M. Iglesia de Santiago de Compostela, Santiago de Compostela, 1898-1911, II, Ap. p. 176, doc. del año 982. Andrade, J. M., O Tumbo de Celanova. Estudio introductorio, edición e índices (ss. IX-XII), 2 vols., Santiago de Compostela 1995, doc. 265, año 982-1001; SÁNCHEZ Albornoz, C., «La repoblación oficial», p. 434, n. 30.

14. Montenegro, J. y Del Castillo, A., «Don Pelayo y los orígenes de la Reconquista: un nuevo punto de vista», Hispania 180, 1992; PAstor Díaz de Garayo, E., Castilla en el tránsito de la Antigüedad al feudalismo. Poblamiento, poder político y estructura social del Arlanza al Duero (siglos VII-XI), Junta de Castilla y León, 1996, p. 119 y s., también sería el caso de Pedro, dux de Cantabria que se habría mantenido independiente.

15. Heather, P., «The Creation of the Visigoths», en Heather, P. (ed.), The Visigoths from the Migration Period to the Seventh Century. An Etnographic Perspective, Woodbridge, 1999. La similitud se extiende al régimen de propiedad. Entre los germanos predominaba la propiedad privada, ver, SCHMIDT-WIEGAND, R., «Marca. $\mathrm{Zu}$ den Begriffen 'Mark' und 'Gemarkung' in den Legesbarbarorum», Untersuchungen zur eisenzeitlichen und frühmittelalterlichen Flur in Mitteleuropa und ihrer Nutzung, I, Göttingen, 1979. En las leyes germanas, la toma de propiedad por aprisión en, MGH. Leges Visigothorum, I, X, 2, 4, p. 392-393. Sobre su conceptualización, expresa Poly, J. P. «La paysannerie libre et la feodalité», en Bournazel, E y Poly, J-P., Les feodalités, «Nommer ces guerriers-laboreurs des IXe et Xe siècles noblesse n'est rien autre qu'un anachronisme patent. S'ils veulent l'eviter, les historiens que rebuterait l'expression "paysannerie libre"devront forger un terme nouveau, quelque chose comme "strate aristo-laborieuse" ou "groupes de producteurs compagnards armés" (p. 193). 
en consecuencia muy mesurada. Es posible que tributos a la circulación y multas cubrieran ese modesto nivel de gastos. Antes que una clase de poder, los testimonios reflejan la imagen de jefes locales que se diferenciaban funcionalmente de los campesinos, y en ello se manifiesta un atributo básico de una estructura social poco segmentada. Examinemos las cosas con mayor detenimiento.

El centro militar, que coordinaba y dirigía actividades que superaban las posibilidades de cada unidad familiar, se correspondía con el interés colectivo de resguardar el espacio. El jefe debía afirmar sus lazos sociales a través de un compromiso personal no delegable, constituyendo más una auctoritas, una autoridad por ascendencia social, que una potestas, un poder de arbitrio. La incapacidad física para la guerra, como la padeció Sancho el Craso (955-957), descalificaba, de la misma manera que los beneficios de sus acciones debían comprobarse: un fracaso, como la derrota de Vermudo I en el Burbia (año 791), acarreaba un descrédito irrecuperable.

Este vínculo, realizado con el prestigio individual y una función reconocible ${ }^{16}$, se desarrollaba en un contexto no restringido a una particularidad signada por expediciones musulmanas. Se inscribía, por el contrario, en un plano sistemático de luchas entre unidades políticas con consecuencias de desvastación de los territorios ${ }^{17}$. No es inoportuno recordar que el eje del surgimiento (y también de la dinámica) del sistema feudal fue la conquista de espacios, y la vía militar fue tan válida como la pacífica toma de tierras por aprisio. Expresado de otra manera, la defensa o la expedición eran ineludibles respuestas sociales ante el progresivo fraccionamiento de la soberanía.

Una apreciación similar puede ser realizada con respecto a la fazendera, el servicio de caminos y puentes que el conde organizaba ${ }^{18}$. También el cobro sobre

16. Ver comparativamente, IRsigler, F., «On the Aristocratic Character of Early Frankish Society», en, ReuteR, T., The Medieval Nobility. Studies on the Ruling Classes of France and Germany fom the Sixth to the Twelfth Century, North-Holland Publishing Company, 1978, p. 112 y s., importancia del carisma en el poder de la nobleza.

17. Un indicio de las luchas locales que se habrían dado desde los primeros tiempos de la Reconquista, lo tenemos en relatos posteriores. Por ejemplo, en Castrojeriz, Muñoz y Romero, op. cit, p. 39, se dice, «In diebus illis venit Didaco Perez et pignoravit nostro ganato, et missit se in villa Silos, et fuimus post illo, et dirrumpimus illa villa et suos palacios, et occiderunt ibi quindecim homines, et fecimus ibi magnum dampnum, et traximus nostra pignora per forza». Sahagún II, doc. 534, año 1049, gobernando el conde Fernando Monniz en Campo de Toro y en Zamora, sus hombres entraron en diversas villas del monasterio de Sahagún, «ingressi fuerunt eius scurrones in uillulis eiusdem loci et amplius in Lampreana et fecerunt ibi quod non licebat». Idem, doc. 404, año 1018. También, España Sagrada, XVI, p. 424. Ver también en Cataluña, la carta de población dada a Cardona por el conde Borrell en el año 986, en Muñoz y Romero, op. cit., p. 53, «faciatis ipsa opera ad ipso castro, id est, turres, et muros,... propter vestras animas ad salvandum sive pro paganis, quam pro malis Xpianis».

18. GonzÁlez, T., Colección de privilegios, franquezas, exenciones y fueros concedidos a varios pueblos y corporaciones de la Corona de Castilla, Madrid 1830, t. V., p. 26, año 1085. Fueros locales de Zamora, doc. 4 , tit. 3 . 
la circulación de bienes podía estar conectado con su protección a las transacciones $^{19}$. Sus servicios otorgaban al sistema una cualidad distributiva.

Pero si el jefe da, el jefe recibe; o más bien, da para recibir. Ese principio antropológico del do ut des, presupone, entre la cúspide y la base, una circulación. La combinatoria de textos con la que construimos el modelo, nos permite apelar a una capitular del año 844, de Carlos el Calvo, dirigida al condado de Barcelona, que nos habla de los regalos que recibía el conde ${ }^{20}$. Este texto indica también un momento de inestabilidad en esa sociedad de estatus. Expresaba allí el rey que si alguien daba bienes al conde en honor y obsequio, esto no podía considerarse un tributo o censo ni el conde o sus sucesores estaban facultados para convertirlo en costumbre. Aparece la conversión del obsequio en tributo, el cambio de la costumbre. En esta transformación se condensa toda la lógica del movimiento de la estructura.

Nuestro punto de partida permite captar el tránsito de la participación general en la guerra ofensiva a tributos sustitutivos como la fosataria ${ }^{21}$. Con este reemplazo de reciprocidades por vínculos asimétricos, se restringía la actividad ofensiva a los agentes condales y a los milites. Los primeros constituían el séquito conda ${ }^{22}$. La situación de los milites, instalados en distintas poblaciones, se conecta con una serie de atributos que se expresan en el fuero de Castrojeriz del año 974, otorgado por el conde García Fernández. Eximía a los habitantes de una serie de cargas, entre ellas la fonsadera, e imponía a los campesinos sin caballo (pedones) tres días de trabajo y un carro de mies a cada uno ${ }^{23}$. Los ca-

19. Los impuestos a la circulación debieron ser antiguos. Se mencionan en muchos documentos desde principios del siglo x. Del Ser Quijano, G., Documentación de la catedral de León (siglos IX-X), Salamanca 1981, en adelante, $D$. Catedral de León, doc. 9, año 916, Ordoño II daba entre otros beneficios y bienes el portazgo de dos días por año de la sal de La Lampreana, «in Lampreiana, de illo portatico de illo sale, in singulis annis duos dies de totas ipsas uillas». Los impuestos a la circulación debieron estar muy generalizados y perduraron. Ver, por ejemplo, Rodríguez, J., Fueros del reino de León, t.2, Documentos, Madrid 1981, en el fuero de León (año 1017) tit. 28, se eximía de portazgo para los que vendían en la ciudad, «et non dent portaticum de omnibus causis quas ibi uendiderint», lo que indica que se cobraba en otros lugares.

20. Praeceptum pro hispanis, año 844, iun II, MGH, Capitularia Regnum Francorum (Karoli II), p. 260, «Si autem illi propter lenitatem et mansuetudinem comitis sui eidem comiti honoris et obsequii gratia quippiam de rebus exhibuerint, non hoc eis pro tributo vel censum aliquo computetur, neque comes ille aut successores eius hoc in consuetudinem venire praesunmat neque eos sibi vel hominibus suis aut mansionaticos parare aut veredos dare aut ullum censum vel tributum aut servitium praeter id, quod iam superius comprehensum est, praestare cogat».

21. Por ejemplo, Del Alamo, J., Colección diplomática de San Salvador de Oña (822-1284), I, Madrid 1950, en adelante, Oña, doc. 107, año 1096, en una donación al monasterio se mencionan las obligaciones debidas al rey, «et hoc totum donamus... absque omni fisco regali, et sine omni exactione, uidelicet: sine annubta et castellera, et fossatera, et omicidio, et stupro».

22. Sahagún II, docs 404, 534.

23. MuÑoz y Romero, op. cit., p. 38, «uno die in barbechar, et alio in seminar, et alio in podar, et singulos carros 
balleros, elevados a la categoría de infanzones (es decir, de la nobleza), iban a la guerra a cambio de un beneficio, excepto aquellos que recibían retribución en metálico y equipamiento militar ${ }^{24}$. De manera concordante con esta especialización, limitaba el conde la participación de los peones y permutaba parcialmente su concurrencia por un tributo en especie. En el caso de que emprendiera una expedición, uno de cada tres peones debía dar un asno y sólo dos tercios de este sector concurría a la campaña ${ }^{25}$. Además, el nivel superior de las poblaciones se articulaba en una jerarquía vasallática: los caballeros tenían derecho a vincularse con un señor (habeant segniorem, qui benefecerit illos).

La autoridad del distrito intervenía, pues, de manera activa en la sociedad campesina, otorgando una forma específicamente feudal a la transformación social (el término feudal se emplea en un doble sentido, como relación económica de señorío y como vínculo de vasallaje). Esa dirección del cambio, o sea la peculiar forma feudal en que se plasmaban las relaciones sociales, surgía aquí de una praxis intencional establecida a partir de un objetivo prefijado. Esa conciencia de la acción proyectada se constituía mediante el derecho, y en este sentido, la voluntad objetivada en la escritura hace que la norma legal aparezca, ante el sujeto histórico y ante el historiador moderno, como la fuerza impersonal que creaba la relación social. Esa dirección específica de la transformación social, que de manera tan luminosa se nos presenta en la observación de la práctica, sería en verdad inexplicable como efecto de un evolucionismo inercial independiente de la conciencia.

Si en el fuero de Castrojeriz se percibe que los milites surgían de las propias comunidades por imposiciones del conde, el documento de los infanzones de Espeja complementa esta observación ${ }^{26}$. Se trata de un texto redactado entre los años 1029 y 1035, referido a los derechos del conde en la merindad de Clunia. Debían hacer los infanzones el servicio de vigilancia ( $a n u b d a$ ) en Carazo y Peñafiel, pero se negaron a cumplirlo. A causa de ello, el conde Sancho García les confiscó los beneficios (presot illecomite tota Spelia), dejándoles sólo sus hereditatelias, es decir, sus pequeñas porciones de tierra, que no diferían de las que tenían los otros miembros de la comunidad ${ }^{27}$. Ese origen popular se repetía en

de messe debere ad illam terra.»

24. MuÑoz y Romero, «Damus foros bonos ad illos caballeros, ut sin infanzones» (p. 37); «caballero (...) qui non tenuerit prestamo, non vadat in fonsado» (p. 38).

25. Idem, p. 38, «Et si illo comite tenuerit arcato, faciant se tres pedones in uno, et de uno illo asino, et vadant illos duos».

26. Menéndez Pidal, R., Orígenes del español, Madrid 1956, p. 35.

27. Estas concesiones dadas a cambio de la vigilancia se expresa en el texto, «Ipsos infanciones de Spelia abuerunt fuero per anutba». Ver comparativamente, SÁEz, E., Los fueros de Sepúlveda, Segovia 1953: en 
otros lugares. En concejos del noroeste de la provincia de Burgos, en las proximidades del año mil, los infanzones estaban integrados en la comunidad ${ }^{28}$. También los infanzones de Langreo tuvieron prestimonios por servicio militar, según se deduce de una escritura del año 1075, cuando mantenían tenencias a cambio del pago de fosatarias ${ }^{29}$. Indiquemos por último que en el fuero de León del 1017 no figura una convocatoria general a la guerra, sino que ordena a los que iban al fonsado con el rey, el conde o el merino, seguir asistiendo según la costumbre ${ }^{30}$. Esta limitación de la práctica militar ofensiva, comparada con los pobladores de Braga participando en las expediciones, mide la degradación del estatuto del campesino libre. Nada indica una excepcionalidad hispánica en este aspecto sino un alineamiento con las determinaciones que se imponían en el feudalismo euro$\mathrm{peo}^{31}$. Con los fragmentarios registros documentales podemos convertir las fases de este desarrollo en un doble análisis de la práctica condal y su traducción en el movimiento de la estructura relacional.

Desde el primitivo poder feudal se constata una articulación entre dispersas unidades familiares recibidas por herencia (que no deben nada porque no son prestimonios), por una parte, y un centro de poder que proveía un eje de unidad y diferenciación territorial por otra ${ }^{32}$. Esa base económica surgía de la libre apropiación de tierras, generando un régimen de propietarios con posibilidades

la frontera de la Extremadura Histórica, al sur de Duero, los infanzones, también estaban integrados a la comunidad junto a los caballeros de la villa. Los milites tenían derecho a buscar señor debiendo en este caso dejar la villa, algo explicable porque se trataba de un lugar de realengo. Dice el titulo 35 del fuero de Sepúlveda del año 1076, «Omnis miles qui uoluerit bene buscare de senior faciat so foro, et uadat a quale senior quesierit, qui non seat nostro guerrero, cum sua casa et sua heredade».

28. Muñoz y Romero, op. cit. año 955, p. 31, «nos omnes qui sumus de concilio de Berbeia, et de Barrio, et de Sancti Saturnino, varones et mulieres, senices et iuvenes, maximos et minimos, totos una pariter qui sumus habitantes, villanos et infanzones de Berbeia et de Barrio, et de Sancti Saturnini».

29. De Hinojosa, E., Documentos. para la historia de las instituciones de León y Castilla (siglos X-XV), Madrid 1919, p.31, «omnes nobiles et infanzones tenentes hereditatem in Lagreio, quos et quantas hereditates aut villas habebant intra terminos de Lagreio, non habebant eas iure hereditatio, sed tenebant eas per manum maiorini Regis usufuctuario et persolvevant per ununquemque anum parti Regis calugnias et fosatarias et qui nolebant istud implere dimitebat hereditatem ex toto et exiebat de predicto valle».

30. Fuero de León, 17, «Illi etiam qui soliti fuerunt ire in fossatum cum rege, cum comitibus, cum maiorinis, eant semper solito more».

31. Basta recordar a título de ejemplo la Capitularia Regnum Francorum, I, MGH, Legum, Sectio I, p. 67, «qui honorati beneficia et ministeria tenent vel bassallatico honorati sunt cum domini sui et caballo, arma et scuto et lancea spata et senespasio habere possunt»

32. El alodio se menciona de manera constante, por ejemplo, O. de las Dueñas, doc. 35 del 997, «karta donatione de terra et de pomare, que abemus de parte de suo patre de Leouina, damus uobis nostra ratione qui nos quadra inter nostros germanos». MuÑoz y Romero, T., op. cit ., fuero de Miranda del Ebro, año, 1099, p. 347, «Et quilibet populator qui tenuerit haereditatem suam pro anno et die sine mala voce, habeat liberam et quietam; et allii qui comparaverint vel acceperint, habeant eam liberam et quietam ad forum de Miranda». 
de participar en las expediciones ${ }^{33}$. Pero ese estadio fue paulatinamente transformado por el desplazamiento de los campesinos de las expediciones ofensivas y la especialización profesional del caballero. El presupuesto fue la percepción creciente de servicios por un segmento social, el de los jefes militares, que cada vez recibían más y daban menos a cambio. Es un punto clave de la metamorfosis de una sociedad de estatus en una sociedad de $\operatorname{clases}^{34}$. La energía social de los campesinos era capitalizada por un jefe que se constituía en un centro de poder ligado a ramificaciones locales con los milites. Esto indica que en las reciprocidades se escondía una desigualdad dada tanto por diferenciaciones funcionales como la jerarquía ${ }^{35}$. Cuando el conde dirigía una expedición y se lograba botín, éste no se repartía entre todos los pobladores sino de acuerdo al rango social. Una evidencia de esto lo proporcionan los esclavos, de procedencia musulmana, que las autoridades militares obtuvieron de sus campañas ${ }^{36}$. Su mención en escrituras, desde el siglo vIII, evidencia el papel que jugaron en las unidades económicas de los optimates ${ }^{37}$. Como consecuencia, la fisonomía de los condados iba a estar

33. La toma de tierras que daba una condición de propietarios independientes ya la hemos visto en el citado juicio de los campesinos de Braga. También O de las Dueñas, doc. 27 del año 993, en una donación de un monte en Valdealiso que realizan siete hermanos para el monasterio de San Juan Bautista y Santa María de la Vega, junto al río Esla, se aclara que ese monte «fuit de patre nostro Quintila et mater nostra Liliolla et fuit de auios nostros de presura»

34. Wickham, C., «Problemas de comparación de sociedades ruralews en la Europa occedental de la temprana Edad Media», trad. esp. Anales de Historia Antigua y Medieval, 28, 1996.

35. Este aspecto que se esconde tras la forma voluntaria del regalo fue detectado por Mauss. Destaca esto, MoREland, J., «Concepts of the Early Medieval Economy», en, Hansen, I. L., y Wickham, C., The long Eighth Century. Production, Distribution and Demand, Brill, 2000, p. 10.

36. La Crónica Silense (España Sagrada XVII, p. 280 ) refiriéndose a la victoria de Alfonso II sobre Mahamud en Galicia en el año 840, dice que le permitió al rey cristiano retornar a Oviedo con cautivos. En la expedición del 860 hasta Talamanca, Ordoño I masacró a los guerreros árabes y vendió al resto de los pobladores como esclavos (España Sagrada XIII, p. 492). Obtuvo cautivos Alfonso III y en el año 897 realizaba una importante donación de «mancipia» a la iglesia de Lugo, los cuales «ex Hismaelitarum terra captiva duximus quinquaginta» (España Sagrada XVIII, p. 285 y XL, Ap. XIX, p. 385). La expedición del rey leonés García en el año 911 le reportó «multa mancipia» (España Sagrada XIV, p. 461. Dos años más tarde, Ordoño II obtenía de su expedición a Evora, «....magna captivorum turba» (Citado por PÉREZ DE Urbel, J. y Picardo del Aerco y Garay, España cristiana. Comienzos de la Reconquista (711-1038), en Menéndez Pidal, R. (dir.), Historia de España, t. VI, Madrid 1956, p. 112). El mismo tipo de testimonios se repiten sobre sucesos posteriores: España Sagrada XIV, pp. 466, 468, 469. En la Crónica de Alfonso III, 10, rebelión de esclavos en el reinado de Aurelio.

37. Martínez DíAz, G., «Las instituciones del reino astur a través de los diplomas», Anuario de Historia del Derecho Español, XXXV, p. 81-82. Mínguez Fernández, J. M., Colección diplomática del monasterio de Sahagún (siglos IX y X), León 1976, en adelante, Sahagún I, doc.9, año 909, Alfonso III dice con referencia a la «villa» de Alcamín, cerca de Tordesilla, «secundum nos illut de squalido de gente barbarica manu propria cum pueris nostris adprehendimus» (p. 37). En el fuero de León del año 1017, título 22, se ordenaba que los siervos fugitivos, «tam de christianis quam de agarenis» debían ser entregados a su señor. 
dada por una población dual de poseedores de tierras sujetos a tributos generales (ingenuos et homines fiscalia) y de no libres (seruos) ${ }^{38}$.

Este cambio de las costumbres no significó la eliminación total de las viejas normas. Antes que un trastocamiento absoluto fue una metamorfosis parcial con preservación de ciertas condiciones de la costumbre que se desplazaba. El campesino reducía su participación en la expedición ofensiva y comenzaba a realizar trabajos para el conde, pero seguía contribuyendo en una gran tarea colectiva, la defensa del territorio ${ }^{39}$. Era éste un aspecto de las solidaridades campesinas por las que el colectivo se comprometía a ayudar a cada poblador atacado ${ }^{40}$. Era también una ocasión para que la potestad política afirmara su cualidad funcional y distributiva. Está contemplada en documentos como el fuero de Palenzuela, localidad al sur este de Palencia, cuya redacción se sitúa entre los años 1074 y 1104. Según se desprende de este texto, el señor era el eje de la organización defensiva dirigiendo a los pobladores «in apellido» fuera del alfoz o territorio, y en el caso de que la volta (el motivo del llamado a defensa) ascendiera a trescientos sueldos, debía proveer una vaca o doce terneros ${ }^{41}$. Situaciones similares se manifiestan en fueros de principios del siglo XIII ${ }^{42}$.

Junto con la defensa, los ordenamientos mencionan la construcción de fortalezas $^{43}$. Son dos actividades discernibles por su significación social. Mientras que en el resguardo del territorio se contemplaban de manera simultánea los intereses del señor y de los pobladores, con los servicios de construcción la acumulación política adquiría un perfil más pronunciado. El trabajo excedente del campesino se objetivaba en un esquema residencial diferenciado, kastrum o palatio, construcciones que, surgidas entre las tierras de labor, se articulaban

38. Alfonso $V$ doc. 15 , a. 1014 .

39. Por ejemplo, Fueros del reino de León, doc. 5, año 1064, fueros dados a la comarca de Valdesaz de Oteros, tit. 13, «Et sonando apellido in no coto uillanus qui ibi non exierit, pectet unam uacam de quinque morabitinos ad concilium».

40. Fueros del reino de León, doc. 51, año 1196, fuero de Molinaseca, tit. 5, «si inimicus alicuius vicini venerit aliunde ad villam vel infra captum eius, omnes vicini debent suum vicinum iubare contra illum et exire in apellido cum suo vicino. Quod si aliquis non fecerit, pectet C morabetinos».

41. MuÑoz y Romero, op. cit. p. 276, «Senior aut merinus qui illos duxerit in apellido foras de sua alfoz primitus det et recabdum de volta sis lebantare, si recabdum voluerit eis dare non vadat cum eo; et si la volta fuerit de trecentis solidis det eis unam baccam, vel duodecim carneros, et si hoc non fecerit non vadit cum illo, et ille qui non fuit in isto apellido cum suis vicinis det unam quartam vini».

42. Fueros del reino de León, doc. 58, año 1205, Alfonso IX obligaba a los pobladores de Laguna de Negrillos a defender la villa en tiempos de guerra. Idem, doc. 67, fuero de Abelgas del año 1217, tit. 7, «si maiorinus apellitum dederit, quid ad illud non uenerit dabit unum carnerum». Idem, doc. 71, fuero de Ribas de Sil, año 1225, tit. 5, «debent autem moratores ipsius terre ire in apellidum domini qui terram tenuerit».

43. Fuero de León, tit. 28, «uigilare illos muros ciuitatis et restaurare illos». 
con la economía doméstica ${ }^{44}$. Su titular podía ser laico o eclesiástico, lo que no quiere decir que el poder de la iglesia pueda ser asimilado en su totalidad a lo que ahora tratamos ${ }^{45}$. Se generaba pues una sede de poder, una estructura política comarcal formada por señores y diversos agentes de control con equipamiento militar ${ }^{46}$. En la medida en que esa organización adquiría una creciente complejidad, desde el punto de vista de las relaciones sociales, la dimensión espacial a cargo de cada titular de mando pasa a ser un aspecto secundario. Podía tratarse de un conde con un campo de gestión restringido o del rey con un derecho más extendido, pero concretado con igual intensidad a escala local por una red de funcionarios que convertían sus distritos en nuevas unidades de soberanía ${ }^{47}$. En cualquiera de los casos, el vínculo establecido entre las unidades

44. O de las Dueñas, doc. 80, año 1016, «terra super kastro»; doc. 85, año 1017, «soto super palatio», illas ceresales, qui sunt in uillas presa so palatio». Alfonso $V$, doc. 18, año 1017, concesión del rey a uno de sus hombres, Pedro Fernández, sobre el Cea, de «kastrum quam dicunt Gundisalbi... cum kasas et omnia intrinsecus domorum et omines ibi auitantes cum terras, uineas, molinis, cum aqueductibus suis». PEÑA Pérez, J., Documentación del monasterio de San Juan de Burgos (1091-1400), Burgos 1983, en adelante, San Juan de Burgos, año 1091, p. 7, donación de Alfonso VI de «omnes illas hereditates que sunt inter duas aquas...usque ad illum meum palacium».

45. D. Catedral de León, doc. 29 del 951-956, Ordoño III daba a la iglesia de León el castillo de San Salvador en el río Curueño, aclarando, «concedimus uobis ad imperandum...qum omni intecritate castellum quod uocitant Sancti Salbatore...qum mandationibus suis vel homines deseruientes». También, idem, mención de castillos en doc. 11 del año 918. Alfonso $V$, doc. 1, año 999, Alfonso V vuelve a dar al obispo de León el castillo de San Salvador de Curueño, «concedimus uobis ad imperandum uel perauendum castellum quam uocitant Sancto Salbatore qui est in Curonio, quum mandationibus suis» (p.165). Como queda expresado aquí, los obispos podían ejercer un papel igual al que tenía el conde. La iglesia de Santiago recibió muchos condados en el siglo x. Al respecto, López Ferreiro, A., op. cit., II, p. 101, 112, 120, 143, 149, 160. Sahagún $I$, doc. 6 del año 904, Alfonso III daba al monasterio poder de mando sobre la villa de Zacarías.

46. Pescador, C., «La caballería popular en León y Castilla», Cuadernos de Historia de España, XXXIIIXXXIV, p. 139, en el testamento del año 1065 de la hija de un conde llamado Sancho, ordena donar los caballos «illis hominibus qui equos tenent de me in prestamento». Sahagún II, doc. 534, año 1049, los «Scurrones» del conde. O de las Dueñas, doc. 61, en el año 1008 el caballo aparece con un valor equivalente a cien ovejas.

47. Aun en el caso de que las concesiones fueran revocadas por el monarca, como muestra $O$ de las Dueñas, doc. 76, eran una fuente de ingresos para el beneficiario. En esta escritura, por la cual Alfonso V daba una corte en territorio de León a Pedro Alvarez por haber abandonado al conde Sancho de Castilla haciéndose vasallo del rey, se recuerda que ese bien había sido otorgado a otros merinos. Dice, «dabo uobis ipsa ereditate ex integra cum homnia sua prestantia, secundum eam obtinuerunt istos meos seruientes». Idem, doc. 23, Vermudo II daba a Froila Vimáraz una heredad en ela territorio de Astorga «propter tuum seruitium que nobis abtum fuit». Tambíen, idem, doc. 95. Cardeña, p. 126. Sahagún I, doc. 19, año 920, Ordoño II da una villa a Taion, al que llama «fideli nostro». En el fuero de León, tit. 16, se establece la autoridad del sayón sobre su mandamento. Sobre este aspecto, sobre el que ahora sólo aludimos, debería procederse a una lectura crítica de ciertas disposiciones. Por ejemplo, en España Sagrada, XVIII, Alfonso IV nombraba a su tío Gutierre «ad imperandum» en una serie de condados en Galicia, aclarando que «omnes ipse populus ad vestram concurrant ordinationem pro nostris utilitatibus». Esta aclaración de que debía ejercer el poder para el monarca no lo transformaba en un funcionario burocrático respetuosos de la norma. Aun cuando el rey expropiaba los bienes concedidos a los rebeldes, en cada insubordinación se manifestaba una autonomía 
de base y el centro regional devenía en una relación de extracción de excedentes que se presentaba bajo la forma de relación política. En consecuencia, la acumulación en el vértice dependía tanto de la movilización de fuerza de trabajo como de una actividad militar ya no sólo orientada hacia el exterior sino hacia el control interno de los pobladores.

Los deberes generales de edificación de fortalezas encontraron su continuidad en el trabajo agrario (seruicium) y la renta en especie (reddant obsequium) ${ }^{48}$. Estas obligaciones que el conde exigía, constituyeron un rasgo perdurable de la estructura $^{49}$. Si bien los trabajos agrarios se inscriben en el mismo tipo de obligación que la construcción de castra, expresan también un cambio relativo en tanto no se destinaban a la formación de recursos específicos de orden político sino a la reproducción global de una clase. La evolución de estos derechos muestra que la aristocracia se organizaba en base a la actividad político-militar en una primera etapa y en una segunda en relación a la actividad rural productiva.

Detengámonos en el mencionado fuero de Brañosera. Establece el conde que los campesinos dent tributum et infurtione, es decir, renta y tributo fiscal. Tal vez nada exprese con mayor claridad la tendencia del proceso que esta identificación. Indica que el poder político se fue convirtiendo en patrimonio, y se marchaba, en consecuencia, hacia una homologación entre lo que los historiadores llama-

política. Esta tendencia fue muy antigua, como prueba, la Ley de Recaredo, MGH, L.V. XII, 1,2, «ut nullis indictionibus, exactionibus, operibus vel angariis comes vicarius vel vilicus pro suis utilitatibus populos adgrovare presumant nec de civitate vel de territorio annonam accipiant».

48. Muñoz y Romero, op. cit., fuero de Castrojeriz. Fueros locales de Zamora, doc. 4, tit. 4. Fueros del reino de León., doc. 3 del año 1042, fuero dado por Fernando I al concejo de Fenar, tit. 1, «Etiam aliis directuris quibus uobis ostendo, in Kalendis martii $\mathrm{X}$ et octo denariis, semel in anno scindete fenum meum et ego dare uobis cibum et potum, similiter singulos dies messes scindet». Idem, doc. 55 del año 1198, en el fuero de Cifuentes de Rueda, el conde Fruela establece que cada poblador trabaje en la serna del señor según la costumbre que tenía de tiempos antiguos, «tantum faciat in nostra senra que est consuetum ab antiquo». Celanova, I, doc. 376, año 962, se menciona «senrra dominica». Esp. Sag., 18, ap. 6, año 917, Ordoño II dio a Mondoñedo, «quadraginta homines tributarii qui reddant per unum dien aprum, dent per singulos annos singulos arietes et quartarios tritici et alium servitium fecuenter exoluant Regalem in idem locum» (p.310). D. de la Catedral de León, doc. 42, Ramiro III daba en el año 981 a la iglesia de León unas «villae» en la ribera del Cea que habían sido de «sequentissimo nostro Furtunius Garseani», «cum suis prestationibus siue et etiam cum hominibus, qui ibi habitant uel ad habitandum uenerint, ut obsequium, quod nobis habebant reddere, post partem ecclesie Dei et uestre persoluant». También, idem, doc. 48, año 991, Vermudo II daba a la iglesia de León las «villae» de Paradilla y Toldanos debiendo sus habitantes seguir cumpliendo los mismos tributos. Un panorama en, del Ser Quijano, G., «La renta feudal en la Alta Edad Media. El ejemplo del cabildo Catedralicio de León en el período asturleonés», en Studia Historica Historia Medieval, IV, 21986.

49. Aunque el peso relativo de las corveas fue en disminución en los siglos siguientes, ver, Botella Pombo, E., La serna: ocupación, organización y explotación del espacio en la Edad Media (800-1250), Santander 1988, p. 68, dice que en el espacio agrario de la Castilla primitiva, entre el mar Cantábrico, y los ríos Arlanzón, Pisuerga, Deva, Oja, Bayas y Nervión, la media de prestación personal era del 30 por ciento en el siglo XI, del 5,5 en el XII y cerca del 4 en la primera mitad del XIII. 
ron tierras dominicales, tierras de señorío y tierras fiscales ${ }^{50}$. Todo el espacio productivo se convertía en una fuente de ingresos señorial, y es posible que ello explique la prohibición que se establecía, en distintos ordenamientos, para que los habitantes de un condado se trasladen a otra jurisdicción ${ }^{51}$. Pero además, se agregaba en el fuero de Brañosera que los campesinos debían dar renta o tributo, quantum poterint ad comite. Ese condicional es significativo. Nos advierte que en la transformación de las obligaciones militares comunitarias a los tributos agrarios habría existido una situación intermedia en la que estas gabelas no estaban delimitadas. Esto se confirma con muchas escrituras en las cuales las obligaciones se exponen en fórmulas imprecisas, como que sirvan los pobladores con todo lo que tienen o que debían realizar lo que se les mandase, reflejo de que los servicios no se habían fijado y eran requeridos según las necesidades de los señores ${ }^{52}$. Sólo de manera paulatina y desigual esos servicios inespecífi-

50. En otros casos la terminología fiscalista encierra un idéntico contenido de renta, como por ejemplo, en $\mathrm{Al}$ fonso $V$, doc. 4, del año 1001, que es una confirmación de una donación anterior hecha por Vermudo II, los habitantes del valle de Castela, cerca del Miño, debían servicios a la iglesia de Santiago, en una forma similar a otros pobladores de una mandación, «in uestris monasteriis seruicium exerceant sicut alius populus ingenuus ut vectigalia vel tributa que fisco solebant exolvere» (p. 171). Esta transformación se cumplía de manera dilatada en el tiempo, pero tenía una dirección de sentido único. Lo muestra la Historia Compostelana, P.L, CLXX, año 1113, decretos dados para regularizar la situación socioeconómica: «De fossataria et luctuosa- Illis qui servilis conditionis jugum sustinent, vel qui quadragesimalia tributa persolvunt, reditus solitos qui fossataria vel luctuosa a nuncupantur, relaxamus, si patrum parentum vel suorum hereditas incolunt» (col. 987). Aquí el servus está asimilado al dependiente fiscal y el tributo que compensaba el servicio de armas era anulado.

51. MuÑoz y Romero, op. cit. en la donación de la villa de Javilla por Fernán González al monasterio de Cardeña en el año 941, le otorga derecho a poblar, prohibiendo hacerlo con los hombre y «villae» del conde, «tamen non de meos homines, et de meas villas, sed de homines excussos, et de alias uillas» (p.25). Idem, en el fuero de Castrojeriz, año 947, los caballeros convertidos en infanzones debían poblar sus heredades con gente de fuera e ingenuos, p. 37, «et populetur suas hereditates ad avenientes et escotos».

52. Las fórmulas pueden leerse en Sahagún I, doc. 6 del año 904, Alfonso III daba al monasterio la «villa» de Zacarías estableciendo que sus habitantes «ad vestram concurant ordinationem pro qualibuscumque utilitatibus eglesie peragendis et quicquid a vobis iniunctum vel ordinatum acceperint». Idem, doc. 7 . D. Catedral de León, doc. 25, año 952, Ordoño III daba al obispo de León el mando de Val de Rotario, como lo habían tenido los antecesores de su padre Ramiro II, y establece que los habitantes «ad uestram concurrant hordinationibus pro nostris utilitatibus peradendis». Idem, doc. 138, año 978, Ramiro III da al monasterio de San Cipriano, la villa de Sahechores con sus habitantes, sujetos a la jurisdicción del monasterio y obligados a los trabajos que los monjes necesitan. Alfonso V, doc. 12, año 1012, en la confirmación de una «villa» dada al monasterio de Santiago se ordenaba que todos sus habitantes «ad ipsum domun sanctum preueant obsequium» (p. 184). Sahagún II, doc. 450, año 1037, María Velázquez dona al monasterio una «villa» con su iglesia que había recibido de la condesa Momadonna, estableciendo que sus habitantes tengan el mismo fuero que han tenido con ella, «talem forum habeant sicut nobiscum habent», y que «seruiant uobis cum omnia que ibidem fuerit». Idem, doc. 436, año 1034, el rey Vermudo III daba el monasterio de Grajal en el río Valderaduey, y los habitantes de su jurisdicción debían hacer «tibi seruicium secundum quod iussionem dederis». Idem, doc. 489, año 1045, el abad Fernando donaba al monasterio una «villa» que recibió del rey, y ordenaba de manera imprecisa que sus habitantes «uobis reddant obsequium sicut usualem habent». 
cos se fijaron en costumbres hereditarias ${ }^{53}$. De acuerdo al carácter local de las transformaciones, en algunos casos a comienzos del siglo x se determinaban las rentas. Por una escritura del 917, de donación del obispo Fruminio a la iglesia de León, sabemos que en la villa de Bercianos sus pobladores debían dar anualmente tributos en especie claramente enunciados ${ }^{54}$. Es posible que ello se debiera a un grado superior de subordinación de esos campesinos con respecto a otros lugares, según se desprende de las limitaciones que tenían para su movilidad, ya que si se trasladaban debían dejar la mitad de sus bienes, y seguían sujetos a la jurisdiccion señorial ${ }^{55}$. Este texto también nos habla del sincretismo de lo que se ha denominado señorío banal y propiedad dominical. La donación tiene la cualidad de un bien patrimonial, pero la renta sólo se podía efectivizar con un poder de mando. Esta simbiosis no se confunde, sin embargo, con las diferencias diacrónicas. En este último plano la prioridad fue política. Las obligaciones agrarias fueron consecuencia de un poder con capacidad para movilizar trabajo, no su causa, y a ese derecho de mando quedó vinculada la renta ${ }^{56}$.

\section{EL ESTUDIO A ESCALA LOCAL}

La función del poder político hacia el año mil, observada a escala local, se encuadra en este desarrollo, y adquiere su real significado en la base productiva, las economías familiares.

Estas unidades domésticas no estaban estructuradas en comunidad sino reunidas en ámbitos de residencia sin organización propia. En ellos, los campesinos, vinculados por parentesco o por simple vecindad, solían reunirse en

53. D. Catedral de León, doc. 29 del 951-956, en una donación a la iglesia de León de una «villa» sobre el río Torío se ordena que los que allí habitaban paguen tributo si lo habían pagado sus antecesores, «uobis reddant obsequium, si equum abii et parentes usuales illis adfuit». También, idem, doc. 37, año 978. Alfonso $V$, doc. 7, año 1009 , los habitantes de Val de Iglesia eran dados al monasterio de Celanova y se establecía «ut faciant ibidem ipsi homines seruicium et obedientiam quod soliti fuerunt facere ad regia potestas». En Muñoz y Romero, op. cit., fuero de Palenzuela, de redacción mas tardía, p. 273-274, las obligaciones se fijan, tanto las rentas en especie como las corveas.

54. D. Catedral de León, doc. 10, «reddant uobis per singulos annos XII modios de ordeo, et XII uizinarios de lino et VI relias»».

55. D. Catedral de León, doc. 10, año 917, «et si de ipsa uilla ductus fuerint ad alia parte auitantes ibi dimitant medietate de omnia rem suam quam abuerint et illa ereditate, et dum ipsos omines ibi fuerint auitantes sic omicidios, furtos, fornigationes, quantumque illis contempserit, ad eglesie sancte uel qui ibi perseuerantes fuerint in Christo pergant quum depregatione et pacto»

56. Además de las muchas menciones en documentos ya citados, D. Catedral de León, doc. 13 año 935, en una confirmación a la iglesia de León de iglesias en Galicia entre los rios Eo y Masma, de donaciones hechas por reyes anteriores, se establece que sus habitantes, «ad uestram concurrant hordinacionem et per annis singulis, huic loco sancto et patri domno Ouecco episcopo... fidelem faciant racionem». 
asamblea, in concilio, para tratar diferentes asuntos de la vida social ${ }^{57}$. Sólo en algunos casos la comunidad se insinuaba como un colectivo poco estructurado; era tal vez un concejo de aldea en una etapa inicial con cierta capacidad para negociar con el poder ${ }^{58}$. En determinadas ocasiones, pobladores asociados por el aprovechamiento colectivo de tierras podían también concretar pactos con los señores ${ }^{59}$. Pero más allá de estas agrupaciones espontáneas, estamos, hacia el año mil, en una etapa anterior a la comunidad; ésta iba a adquirir su verdadera entidad en tiempos posteriores, con la organización institucional.

Estas economías domésticas revisten una cierta complejidad reconociéndose por lo menos tres niveles. Su núcleo era la «corte», la parte de la casa con sus construcciones accesorias y un espacio cercado ${ }^{60}$. Además de la huerta o los frutales próximos a la residencia, de ese contorno saldrían también sencillas manufacturas como los textiles. Desde ese centro se dirigía el campesino a sus tareas en viñas, cereales y frutales, que constituían un segundo nivel de organización. Por último, las tierras comunales y los medios de producción compartidos eran complementos de la vida del campesino ${ }^{61}$. Un régimen de familias nucleares

57. O. de las Dueñas, en doc. 27 se menciona un monte en propiedad de siete hermanos. Teniendo en cuenta que este tipo de tierras eran complemento de las parcelas individuales, es muy posible que allí se encontrara una unidad de residencia formada por una familia extensa. En buena medida, las uniones por parentesco estarían vinculadas a herencias compartidas, como la que se menciona en, idem, doc. 93, «uilla de Aralia, qui fuit de Materno et laxabit illa ad suos filios, et conceserunt ea post parte eclesie Sancti Christoforis». Pero la impresión que se obtiene es que los lazos eran vecinales en su mayor parte. Las asambleas las conocemos por la participación del conde en juicios, aunque debían realizarse en muchas otras ocasiones; al respecto, idem, doc. 117, año 1022, «concilio de omines bonos»; doc. 138, año 1027. También, Cardeña, p. 300; Alfonso V, doc. 9; D. Catedral de León, doc. 63, año 908. Unidades de residencia sin estructura concejil, siendo nombrados los pobladores a título individual, en Alfonso $V$, docs. 7, 8 .

58. El mencionado acuerdo del año 971 del concejo de Agusyn, éste se manifiesta compuesto por todos los jefes de familia, 41 hombres lo suscribe, y entre ellos se menciona un sayón que sería del concejo. SÁNCHEZ Albornoz, Despoblación y repoblación del valle del Duero, Buenos Aires, 1966, p. 331, n. 133, plantea que sería ya un concejo rural. Es posible. Pero se trataría de una organización muy simple.

59. D. Catedral de León, doc. 105 del año 955, los habitantes de tres lugares que trabajaban en común el monte de Pardomiro, acuerdan pagar a los monjes de Pardomiro la cuarta parte de lo que recogían en las tierras del monasterio bajo la pena de pagar cada uno diez bueyes. Se mencionan 21 pobladores. Cardeña, p. 213, año 932, en un juicio condal entre los dueños de molinos de unas villas y el abad de San Torcat, se dice que el pleito estaba establecido «cum omnes meos heredes qui sunt heretarios in illos molinos», concurriendo todos a un juicio abierto, con participación general, «et alii multitudinem syne numerum venerunt».

60. O de las Dueñas, doc. 64, año 1010, «corte conclusa con suas kasas et con suo exitum et terra». Idem, doc. 69, «corte cum tres kasas materazas et sua iacentia, et terra et uinea». Sahagún II, doc. 368, año 956, «cohorte nostra propria conclusa, cum suas casas». Idem, doc. 374, año 1001, «corte cum suos solares et suo orto et suo pomare». Idem, la corte con sus heredades es mencionada en docs. 413, 477. El huerto también sería un lugar cerrado y próximo a las casa, según se ve en Cardeña, p.73, «orto concluso...in civitate Vurgos in parte Occidente iuxta orto de Belendo».

61. Sobre estas unidades complejas, por ejemplo, O de las Dueñas, doc. 61, en una transferencia de la parte de una villa que pertenecía a un poblador, se mencionan «terras, pumares, totas orbuscula prestantibile, mon- 
(sólo ocasionalmente se mencionan tierras compartidas por varios familiares, y ello no necesariamente significa parentesco extenso) proporcionaba una mano de obra con división sexual del trabajo adecuada para ese régimen tripartito ${ }^{62}$.

Pero nuestras preocupaciones no se dirigen ahora a ese modo de producción doméstico como tal sino a su atributo relevante: la «casa total» reunía las condiciones básicas de su reproducción. Con una tendencia autosuficiente, la organización comunitaria debería jugar un papel en la coordinación del interés del vecindario. Sin embargo, esta organización era rudimentaria, y se limitaba a las asambleas de vecinos. No se puede distinguir un poder interno de control en las aldeas ni ninguna institución. Se abría pues un espacio para la intervención condal, y en este nivel se determinaba el tipo de relación que se establecía entre la base productiva y el poder superior, apenas mediada por homines bonos ${ }^{63}$.

Desde el momento en que la sociedad se encontraba atomizada en unidades que debían coordinar aprovechamientos colectivos, se tornaba necesaria una autoridad situada por encima del interés particular ${ }^{64}$. Este requisito era todavía más evidente si tenemos en cuenta que en un régimen individualizado, cada producción se encontraba en potencial antagonismo con otra similar, como lo muestran los conflictos que emanaban de la convivencia. Los campesinos, con recurrentes dificultades por límites entre sus posesiones o por su participación en complejos

tibus, fontibus, pratis et pasquis, exitis, aquis aquarum, molinarias, piscazionibus». La reiterada mención de estos factores de producción está lejos de constituir un tópico. Unidad familiar, idem, docs. 16, 20, 21.

62. La herencia era tanto por vía del padre como de la madre. Lo dicen documentos del ámbito que ahora analizamos, pero sería un rasgo general. En Loscertales de G. de Valdeavellano, P., Tumbo del monasterio de Sobrado de los Monjes, I., Madrid 1976, (en adelante, Sobrado de los Monjes), se dice de una heredad campesina situada en la villa de Codegio, «habemus ipsam hereditatem de successione matris nostre Trudildi, quam illa habuit de matre sua Seniorina». La importancia del trabajo de los dos miembros de la pareja fue un rasgo estable de la economía campesina, y se muestra en ordenamientos posteriores en los que se disminuyen las rentas que pagaban las unidades donde moría uno de los cónyugues. Ver por ejemplo, Alonso Martín, M. L. y Palacio SÁnchez-Izquierdo, M. L., Jurisdicción, gobierno y hacienda en el señorio de abadengo castellano en el siglo XVI. Edición y estudio de las informaciones de Carlos V de 1553, Madrid 1994, p. 177, 196, 197. Esta producción atomizada tiene muchos paralelismos con lo que SAHLINs denominó modo de producción familiar, Sahlins, M., «Economía tribal», en Godelier, M. (comp.), Antropología económica, trad. esp. Barcelona 1976. Cfr. SIVERY, G., Terroirs et communautés rurales dans l'Europe occidentale du Moyen Age, Press univ. de Lille, 1990, p. 73, «Tous les dénombrements carolingiens des libres, demi-libres, non libres montrent la famille monogamique».

63. Junto a muchas intervenciones directas del conde sobre la familia, en $O$ de las Dueñas, doc. 146, en un juicio por heridas, se dice «et rocamus uobis [Froila Muñoz] cum homines bonos». También, doc. 122.

64. El sistema de canalización de aguas aparece mencionado en muchas ocasiones, por ejemplo, $O$ de las Dueñas, doc. 55, y ello debió requerir de alguna forma de coordinación. Era también una situación general, Cardeña, p. 213, conflicto entre el monasterio y aldeas por la utilización de aguas en el año 932. Muchos otros debieron darse entre aldeas y entre campesinos. Idem, p. 44, año 955, un campesino vendia al monasterio un canal de agua que salia del Arlanzón. No sólo se usaba para el riego, idem, año 932, p. 213, el conde Fernán González prohibía a los dueños de los molinos situados entre Castañares y Burgos que quiten el agua a San Torcat. 
derechos de uso, complejidad que invitaba al robo o a la entrada en tierras ajenas, requerían de algún nivel de regulación de las relaciones ${ }^{65}$. El trabajo rural era una fuente de resentimientos interfamiliares que podían desgarrar el tejido social si se los dejaba actuar libremente ${ }^{66}$. El conde, con una relación inmediata con cada unidad familiar ${ }^{67}$, se erigía en un mediador de los nexos sociales, en un jefe de comunidad, y los campesinos eran conscientes de esta necesidad recurriendo a su arbitrio. El propio damnificado recibía una compensación moral e incluso podía compartir alguna porción de la multa condal ${ }^{68}$. El señor vigilaba y condenaba cada delito con la pérdida de alguna propiedad que pasaba a su patrimonio. Robos, agresiones y homicidios, se transformaban así en un instrumento dual de absorción señorial de propiedades y de justificación de la autoridad ${ }^{69}$. En tiempos posteriores esas funciones serán realizadas por la misma comunidad ${ }^{70}$.

65. O de las Dueñas, doc. 56, año 1006, Pedro Flaínez obtenía tierras y frutales, «pro iudicio que nos petibit Fredinando Muca, in uoce de suo socro Cibriano, pro III raciones que abuit in tres pumares». Cipriano y sus hijos son mencionados como linderos de las propiedades cedidas. Este tipo de antagonismos y competencias son una constante de las comunidades campesinas de la Edad Media. Es posible que muchos conflictos se originaran por invasiones de tierras. Por ejemplo, O de las Dueñas, doc. 92, año 1019, entrega de una tierra en Valdoré a Pedro Flaínez por quebrar unos linderos; doc. 122, año 1022, el conde obtiene una tierra por el delito de usurpación de una heredad, «se leuauit Arias per uiolenzia et inuassore in ipsa ereditate».

66. Venganza intrafamiliar ha quedado en el fuero de León, tit. 24, «Si quis homicidium fecerit et fugere poterit de ciuitate aut de suo domo, et usque ad nouem dies captus non fuerit, ueniat securus ad domum suam, et uigilet se de suis inimicis».

67. $O$ de las Dueñas, doc. 44, año 1001, el conde había establecido un pacto con tres cabezas de familia (dos hombres y una mujer) por el cual estos no podían cambiar de señor trasladándose a otra mandación, habiendo fiadores del pacto. Estamos ante una relación individualizada sin mediación de la comunidad. También idem, doc. 74. Era una relación con la familia como una unidad, como lo muestra el hecho de que el delito cometido por un hijo afectaba a todo el núcleo doméstico.

68. O de las Dueñas, doc. 122, año 1022.

69. O de las Dueñas, doc. 36, un campesino de nombre Belido fue encerrado en su corte por Caradona, y ésta es llevada a juicio por el damnificado lo que provocó que perdiera una viña, «et dabo uobis illam [uinea] in uestro iudigado pro illum iudicium quem abuit zum Belido pro que inclusit illum in sua zorte et inuenit me iudizius» (p. 6). Idem, doc. 72, año 1013, entrega de bienes por homicidio y robo en viñas «Pro que ocisit Abeiza et fecit omecidio, et pro ipsas uinias que uendimiauit per furto». Idem, docs. 59, 60, 82, 103, 109, 146, 26a. En otros lugares las cosas no eran diferentes, ver, Sobrado de los Monjes, doc. 21, año 931, juicio por el robo de 30 bueyes; Idem, doc. 54, año 930, delito de hurto.

70. El señor delegaba entonces en la organización interna y semi autónoma de la aldea funciones de coordinación en el aprovechamiento colectivo de los comunales, de policía, de extracción de rentas y de canalización del conflicto. Esta función de las autoridades de las aldeas justifica que sus nombramientos hayan sido alentados por los señores. Un ejemplo temprano en, Fueros del reino de León, doc. 3 del año 1042, fuero dado por Fernando I al concejo de Frenar, estableciendo que se reúna en Burgos para resolver sus normas y juicios, tit. 12, «concilio isto debet congregare in uerruga pro suis foros et iunctas et iudicios et totos suos directos». Idem, doc. 18, fuero de Castrocalbón dado por la condesa María en el año 1152, ordenando que haya jueces electos para juzgar a sus pobladores, tit. 1, «mando...ut iudices electi habeantur in castro galuon qui iudicent causas ibi morantium». En Palenzuela, MuÑoz y Romero, op. cit, p. 275, «Si senior de Palenciola, aut aliquis infançon de foris villa, aut merinus villae, aut vicinus habuerit rancuram de ali- 
La intervención múltiple del conde se adaptaba así a la lógica de la reproducción campesina. Si el campesino procedía a la compra-venta de bienes, como respuesta a las variaciones del ciclo familiar o a las oscilaciones de la pobreza, el conde participaba de ese mercado ${ }^{71}$. Lo mismo puede decirse de la profiliación. Con esta figura, una familia campesina adoptaba un niño y terminaba convirtiéndolo en heredero ${ }^{72}$. Era un recurso similar en su objeto a la compra-venta de tierras, en tanto se lograba adecuar el trabajo al espacio disponible. En ciertas ocasiones, el traspaso de tierras hacia el conde se realizaba mediante una carta de profiliación, por la cual éste se interponía en la línea de los herederos campesi$\operatorname{nos}^{73}$. Este procedimiento revela que el intervencionismo condal se realizaba en compatibilidad con los fundamentos de la sociedad rural. Si el labrador establecía con la tierra una relación orgánica, tomándola como una parte inalienable de sus condiciones de existencia, con la adopción el bien no salía formalmente del seno familiar, siendo el conde el que se transmutaba en parte de la familia situándose en la secuencia de transmisiones campesinas ${ }^{74}$. Las formas aparenciales que encubrían el contenido de la relación se daban también en las sentencias judiciales por las que el campesino transfería sus heredades al conde como venta ${ }^{75}$.

También el préstamo en especie, el renovo, se inscribía en la esfera de las necesidades. Si los estudios determinaron que cada veinticinco años había en promedio dos años sucesivos de malas cosechas, esta práctica de subsistencia era un requisito de reproducción que originaba una circulación de bienes en préstamo entre los campesinos ${ }^{76}$. Ofrecía también la oportunidad para la intervención

quo vicino veniat ad suum concilium». En la Baja Edad Media los procuradores cumplían funciones en la recaudación, además de tener un rol en la domesticación del conflicto, y eran en consecuencia amparados por el señor. Lo estudié en, Astarita, C., «Representación política de los tributarios y lucha de clases en los concejos medievales de Castilla», Studia Historica. Historia Medieval, 15, 1997.

71. O. de las Dueñas, docs. 40, 50, 51, 54. Operación de compra-venta entre campesinos de cinco tierras, algunas en su totalidad, otras sólo de fracciones por el precio de un buey y un cerdo en idem, doc. 20 .

72. Sahagún II, doc. 533, año 1049, Domingo Jiménez y su mujer profilian a Jimena, «criata nostra», y a sus padres con sus bienes que tienen en San Feliz del Curueño.

73. O. de las Dueñas, doc. 43, año 1001, doc. 52a, año 1003, doc. 139, año 1027. Sahagún II, doc. 395, año 1009; doc. 480, año 1044

74. Estas transmisiones podían ser por compra-venta, trueque o profiliación. $O$ de las Dueñas, doc. 58, en un cambio de tierras del conde con dos hermanos, estos declaran haberla recibido por profiliación, «kartula concapiacionis de eridate que fuit de Iulianu, que abemus per karta profiliacionis» (p. 80). El lazo inquebrantable de las familias con sus tierras en épocas prefeudales y medievales en, GuRIEvich, A., Historical Anthropology of the Middle Ages, Polity Press, 1992, p. 178. Vid. también, Braga DA Cruz, «Algunas consideraçóes sobre a «perfilatio»»», Boletim da Faculdade de Direito de Coimbra, XIV, 1937-1938, p. 407 y s.

75. O de Las Dueñas, docs. 58, 59.

76. O de las Dueñas, doc. 25, Flaín Muñoz recibía tierras por el no pago de una deuda entre vecinos. En $\mathrm{Sa}$ hagún II, doc. 533 del 1049, los campesinos que profilian reciben en corroboración, junto a otros bienes, cuatro sueldos de «renovo». 
del conde como comprador pagando con alimentos, o como «banquero tribal», para retomar una expresión de Malinowski, y era asimismo el medio para lograr una transferencia de propiedades cuando el campesino no podía devolverlo ${ }^{77}$. En tiempos posteriores encontramos que ese banquero de la tribu será el campesino «rico y abonado» que lograba relaciones de clientelismo con sus vecinos menos favorecidos ${ }^{78}$. La permanencia de esta práctica muestra que era indispensable recurrir al que había conservado el grano cuando peligraba el nivel mínimo fisiológico de reproducción, y ello explica la variedad de sus protagonistas. En el espacio que ahora observamos, no sólo se aprovechaba el conde de las oscilaciones de esa máquina imprevisible que es la naturaleza. Revoloteaban también pequeñas aves de rapiña que se cebaban con las urgencias de los campesinos, y mediante el renovo o transacciones engordaban su patrimonio ${ }^{79}$. Este procedimiento del conde, por otra parte, está próximo en sus resultados a las compras que realizaba de porciones de tierras delimitadas de modo particular en los grupos sociales. Cuando un campesino entregaba la fracción heredada que tenía con sus hermanos, su parte en el molino comunal, o, como en Cardeña, sus derechos en las explotaciones de sal, el señor pasaba a participar de un sistema comunitario $^{80}$. Se sumergía en la racionalidad campesina porque él mismo compartía esa racionalidad como titular de una economía consagrada a los valores de consumo. En múltiples ocasiones pagaba sus compras de tierras con bueyes, ovejas o granos, o participaba de las explotaciones colectivas ${ }^{81}$. Desde otro punto de

77. O de las Dueñas, doc. 34, año 995, pérdida de un linar, la tercera parte de una corte y de un huerto por una viuda que no puede devolver el préstamo que había obtenido con su marido en vino y grano; doc. 75, año 1015, Pedro Flaínez compraba una tierra por tres medidas de grano; doc 114, año 1022, compra de unos manzanos por «III quartarios de ceuera»; doc. 159, año 1034, venta de una tierra al conde por dos cabras preñadas, un cuarto de grano y un queso. El préstamo señorial de granos también en $T$. Celanova, docs. 98 y 99 del año 952. Malinowski, B., «La economía primitiva de los isleños de Trobiand», en Godelier, Antropología y economía, p. 96.

78. Casado H., Señores, mercaderes y campesinos. La comarca de Burgos a fines de la Edad Media, Valladolid 1987 p. 523 . Muchos serían mercaderes de aldea, ver, Cortes, Madrid 1882, vol. 4, de Valladolid de 1537, p. 677.

79. O de las Dueñas, docs. 10,11,12,12a, 13, reflejan las actividades del presbístero Braulio como comprador de tierras, a veces pagando con pequeñas medidas de grano, y como prestamista.

80. O de las Dueñas, doc. 54, año 1006, «mea ratione qui me quatra inter meos germanos uel eredibus uindo uobis et concedo»; doc. 85, año 1017, venta al conde, entre otros bienes, de «mea ratione in illo molino cum suo adtondo et cum suo aquaducto»; doc. 89, año 1019, Froila Muñoz al comprar una heredad recibía el derecho al uso del molino por un día y noche. La participación del conde en los derechos de los molinos campesinos no difería de lo que se encuentra en los textos eclesiásticos. Al respecto en Cardeña, p. 49, 60, 352, participación en los molinos. Por ejemplo, en idem, p. 133, el derecho transferido era de usar el molino una vez cada doce días, «vice de molino... ad XII dies die et nocte». Idem, p. 301, 310, 311, participación en la explotación de la sal.

81. Los campesinos tenían necesidad de reponer sus animales de trabajo (en tiempos posteriores hay indicaciones de que constituyeron objeto de un comercio muy beneficioso para los mercaderes). En $O$ de las 
vista, esto muestra que entre el alodio campesino y el señor no había una barrera infranqueable sino múltiples empalmes productivos.

Pero el conde no participaba sin modificar. Si con la profiliación afirmaba una práctica campesina, al mismo tiempo la negaba alterando la reproducción intergeneracional. Mientras que la sociedad campesina usufructuaba colectivamente del molino, introducía un principio diferenciado con su propio molino ${ }^{82}$. Cuando los hombres buenos de la aldea se reunían para resolver sus diferencias, podía presentarse ante esa asamblea como un testigo calificado que garantizaba que de una deliberación surja una sentencia inapelable. Para el aldeano podía tornarse imprescindible comprar ese testimonio que volcaba a su favor las opiniones ${ }^{83}$. Lo mismo ocurría con la explotación compartida de ciertos espacios. Los productores necesitaban una regulación de los usos comunales (no podía permitirse que un campesino llevara un número desproporcionado de animales a pastar, como muestran las ordenanzas del tardo medioevo). Tampoco podía permitirse lo que hicieron Dono, su hijo Leovigildo, Maxito y Vermudo, que no sólo talaron el monte sino que también (algo que hicieron los campesinos durante toda la Edad Media), corrieron los límites para ampliar la extensión aprovechable ${ }^{84}$. Reprimir esto era a medias una necesidad de la aldea y una necesidad del señor, y sobre ella actuaba el conde favoreciendo sus intereses (o los de un señorío monástico como el de Cardeña) limitando el libre uso del comunal ${ }^{85}$. En ciertas circunstancias, descubrimos una simbiosis de prácticas. En el año 1032, un matrimonio profiliaba a la hija de Froila Muñoz en su villa y heredad en retribución de su ayuda en la asamblea judicial ${ }^{86}$.

La condena de las transgresiones alcanzaba al adulterio, y en ello volvemos a encontrar una ambivalencia en la intervención condal. La convivencia podía

Dueñas, vemos al conde que compraba muchas veces tierras por el precio de un buey, en docs. 104, 105, 106, 128, 158. Cuando el conde se quedaba con las veces de un molino, y ello era relativamente frecuente, se incorporaba de alguna manera al colectivo. Comparativamente vemos que en Cardeña, año 902, p. 120, el conde Gonzalo Téllez daba bienes al monasterio, y entre lo donado mencionaba «in salinas areas numero XXI». Idem, año 972, p. 337, el conde Garci Fernández donaba un pozo de sal en Granadera, territorio de Oña.

82. San Juan de Burgos, p. 7, en una donación de Alfonso VI del año 1091 se menciona «molendino comitis». También los monjes tenían sus propios molinos, según se dice en Cardeña, p. 81, cuando una familia vende al monasterio una tierra en Ibeas, «iusta vestros molinos».

83. O de las Dueñas, doc. 35, año 997 , «damus uobis ipsa ratione in beneficia que mandedis, et deatis mici ueridatem cum meos intentores que abeo pro illo kanado uel ereditatem de Ermegildo, presbister». Idem, docs. 94, año 1019; 129, año 1024; 138, año 1027.

84. O de las Dueñas, doc. 117, año 1022, «pro ipsos montes...que taliaront et dekaluaront et proro illas arcas petrinias que conmouerunt, in ipso monte».

85. Cardeña año 972, p. 9, p. 334..

86. O de las Dueñas, doc. 152, «que abeamus de uos ausilium et aiudorium in concilium». 
alterarse si un marido se descubría engañado, y no sólo debía irritarse por haber perdido el monopolio de una relación. En una sociedad en que los vínculos eran cara a cara, donde cada domus tenía su autoridad masculina, y el reconocimiento social podía verse comprometido por la murmuración o el escarnio, la infidelidad era algo para tomar en serio. Lo que le ocurría a otro podía también sucederle a uno, y por eso el cornudo representaba un peligro para todos. Estos problemas eran materia de inspección y vigilancia general. Así lo experimentó Aurelio, conducido al concejo judicial por haberse entreverado con la mujer de Arcayo. Como un vecino calificado, Froila Muñoz colaboró para establecer que fue la inquina de sus «enemigos» el motivo de la acusación, y Aurelio, liberado de todo cargo, dio entonces in ofercione, en reciprocidad, una tierra a quien lo había ayudado tan eficazmente ${ }^{87}$. En muchas ocasiones se repetía este arbitraje, aunque usualmente se condenaba al acusado. Este delito era frecuente, explicable tal vez por hábitos de convivencia y trabajo que favorecían los contactos, y el conde hallaba muchas oportunidades para extender sus tierras cada vez que uno de estos asuntos era tratado en juicio. Pero una vez más, el conde correspondía al interés general como un campesino y modificaba como un extraño. En cada una de las condenas, introducía nociones que no tenían porqué ser consustanciales de la sociedad, como las de prohibición endogámica, indisolubilidad del vínculo y continencia para el que había elegido el casamiento espiritual con la iglesia ${ }^{88}$. Incluso nociones de parentesco artificial: una familia campesina perdió una corte en el territorio de Ordás porque uno de sus hijos cometió adulterio cum sua comatre, dejándola embarazada ${ }^{89}$.

No es fácil encontrar una explicación para estas preocupaciones morales del conde. Descartemos que la predicación eclesiástica haya modelado una mentalidad de asceta, aunque debió proporcionar una valiosa herramienta de coerción. A juzgar por los numerosos bastardos, los señores de la Edad Media regían su

87. O de las Dueñas, doc. 129, año 1024, como surge del texto, se trató de una acusación en la que participó un colectivo, «levantarunt crimine super Aurelio, que erat mesco con mulier de Arkaio, et deuenimus inde at concilio et ante Gaudinas, iudigum, et concilio de Uiniaio, et peresquisierunt inde et era ibso Aurelio sano de ipsa crimine et per apostura aposuerant super illo suo enemigos. Pro que fuit Froila Moniz suo adiutatore et ahallazabit ibso Aurelio de ibsa crimine sano».

88. O de las Dueñas, doc. 26, año 992, Fredino y su mujer perdían tierras porque el primero indujo a su hijo a ir a la casa de Lecinia de noche, cometiendo fornicación, delito agravado por ser parientes en tercer grado. Idem, doc. 55b, año 1006, Justa debió dar sus tierras al conde por haber cometido adulterio con el marido de su hermana. También, delito de adulterio, en idem, docs. 31, 32, 55b. Idem, doc. 103, delito por separarse de la mujer. Idem, doc. 74, año 1014, Vitalia debía entregar la villa y heredad que tenía en Lorma, donde Pedro Flaínez tenía la mandación por haber cometido un delito con un monje. Creo que se trató de una transgresión sexual.

89. O de las Dueñas, doc. 127, año 1024. 
conducta por una ética que no era la que imponían sobre sus poblaciones ${ }^{90}$. En las condenas al delito sexual, al igual que en las escrituras doctrinales, hallamos en realidad una faceta de la «formación de una sociedad represora»" ${ }^{91}$ que a veces los historiadores olvidan registrar. Pero una sociedad represora (y la represión sexual) no es un objeto por sí mismo. Es un instrumento de la construcción de las relaciones sociales. Empezando por la más inmediata razón económica, cada pareja era una célula de reproducción social, y por ello, controlar el intercambio matrimonial figuraba entre los desvelos del conde ${ }^{92}$. Ese núcleo de producción debía ser institucional y consagrado, preservado de conflictos que lo alteren. Las inclinaciones hacia una sexualidad libre debían corregirse, y la conducta se domesticaba con una doctrina que el conde no tenía porqué cumplir. Incluso una violación ostentosa de las normas que debían regir la sociedad, convirtiendo el derecho a esa libertad en un monopolio, podía ser para el conde un recurso de diferenciación (y esto no es muy distinto al privilegio exclusivo de la violencia). El problema está entonces en constituir un dominio sobre la persona que presupone el autodominio (impuesto) de la persona misma ${ }^{93}$. Pero además, desplazando a las familias en la resolución del litigio no sólo se redefinía el principio de tratamiento colectivo, sino también el de compensación. Junto con el juicio que se iniciaba por la demanda de la parte afectada, aparecía el delito determinado por la autoridad convirtiéndolo en un abstracto general, como en el año 995, cuando el representante del conde acusaba a un poblador de haber cometido adulterio con la mujer y la hija de otro hombre ${ }^{94}$. Los instrumentos de poder eran pues también rescatados de las prácticas aldeanas, se mezclaban con la sabiduría erudita y en consecuencia eran trastocados. Se constata en otros aspectos. Según aseveran algunos historiadores, en el veredicto de la ordalía

90. Me apoyo en las investigaciones inéditas de Romualdo Saenz Matienzo, investigador que ha reunido una magnífica información sobre esto.

91. Moore, R.I., La formación de una sociedad represora. Poder y disidencia en la Europa Occidental. 950-1250, trad. esp. Barcelona 1989, p. 151 y 154.

92. En un texto que no pertenece a nuestra zona, se manifiesta esto. LóPEZ FerreIro, op. cit., II, Ap. LXXXIII, p. 201, acuerdo entre los condes de Carnota y Avianco durante el reinado de Ramiro II, «Et quanti uenerint ad habitandum de comitatu de Cornati in comitatu de Auiancos, acciperent inde uxores et hereditates parti comitatus seruirent. Et qui uenirent de comitatu de Auiancos in comitatu Cornati, acciperent inde uxores et hereditates, et starent parte ipsius comitatus ingenuos».

93. Cfr. Elias, N., El proceso de la civilización. Investigaciones sociogenéticas y psicogenéticas, trad. Esp. Buenos Aires 1993.

94. O de las Dueñas, doc. 31, «Manifestum sum ego Flaino ad peticione Elias, qui asere uoce de comite Flaino Monizi...toliuit ego Flaino muliere aliena ad suo marito et fecit qum ea adulterio et post et sic fecit qum sua filia, qum matre et filia». 
el individuo ponía a prueba sus vínculos sociales ${ }^{95}$. El conde reformulaba esa práctica desterrando el juicio de la comunidad. Obligaba al acusado a demostrar su inocencia con la prueba del agua caliente, y si éste deseaba eludirla, le cedía su propiedad ${ }^{96}$.

Podemos alcanzar entonces una nueva conclusión que nos aleja de una visión funcionalista de este poder de función: el señor se sumergía invasoramente en la conflictiva sociabilidad campesina, participando de su racionalidad, para alejarse de ella y enfrentarla. En este posicionamiento afirmaba sus prerrogativas, su distinción jerárquica y sus cualidades de clase como otros tantos atributos de su persona. El mismo empleo de la escritura, a cargo de los agentes condales, fue un aspecto de esta segmentación social ${ }^{97}$. Estamos ante una práctica ambivalente que inscribiéndose en necesidades de los productores, preservaba el modo material de producción al mismo tiempo que transformaba las relaciones sociales.

En todo esto se dirimía una reformulación de costumbres más que su imposición ex nihilo, de la misma manera que hemos visto esa reformulación en el pasaje de los deberes militares a los deberes de trabajo. Veamos algunas circunstancias en particular.

El desigual valor del testimonio en un juicio era una noción que se tenía desde hacía mucho tiempo, y que no sólo invalidaba al esclavo: en la ley visigoda se descalificaba al indigente ${ }^{98}$. Esta tradición era recogida y reformulada por el señor, y el aldeano se veía obligado a acogerse a la tutela del poderoso. Una cuestión similar se daba con respecto a las parejas. El matrimonio no era un presupuesto de la sociedad, y en textos muy posteriores, descubrimos que los campesinos no siempre se esforzaban por cumplir con ese sacramento ${ }^{99}$. Ciertos pobladores de nuestra porción de tierras leonesas también vivían despreocupadamente en concubinato ${ }^{100}$. El conde se apoyaba entonces en la forma espontánea de la alianza para transformarla en una institución, en matrimonio. Este debía ser, además, indisoluble, una condición que ignoró Fernando cuando abandonó a su mujer Leocadia, uniéndose en adulterio con Justa, que había estado casada con

95. Resumen de estas opiniones con aportes propios en, Moore, La formación de una sociedad represora, p. 151 y 154.

96. O de las Dueñas, doc. 24, «de post fidelem datum pro manum mitere ad inocentiam». Idem, doc. 123, «damus ad uobis ipsa terra pro que abemus iudicio con Aita Cidici et erepimus uobis de illa calda que nobis bene conplacuit», idem, doc. 94 .

97. O. de las Dueñas, doc. 74, año 1014, «facimus placitum per scriptum... super manum sagione»

98. MGH, LL, sec. I, vol I, II, \$, \#, p. 96, «nam videntur esse cavendum, ne forte quisque compulsus inopia, dum necessitatem non tolerat, precipitanter periurare non mentuat».

99. Blasco, R., «Ordenanzas municipales de Villatoro (Avila)», en Anuario de Historia del Derecho Español, 1933, p. 420.

100. O de las Dueñas, doc. 127, año 1024. 
su hermano. Atentó también contra la familia como organización económica llevándose la dote de su esposa legítima ${ }^{101}$ ¿Sabía por otra parte Fernando que agravaba las cosas uniéndose con una mujer en un grado de prohibición eclesiástica? Posiblemente lo desconocía. No debemos pensar que las relaciones exogámicas nacieron espontáneamente, como lo atestiguan muchas sanciones a la fornicación entre parientes (incluidos los que entraban en el parentesco artificial). Ello no significa ausencia de normas (los campesinos las tenían ${ }^{102}$ ), pero a esas reglas el conde superponía sus propias normas. Entre tantos otros, las aprendió Auria, que encontró el placer con su primo Algastre, secundum lex non docet, quedando embarazada ${ }^{103}$. Auria debía ser castigada en público, con la flagelación, para que todos memorizaran lo que la ley enseña y recordarlo día a día con la observación de un cuerpo lacerado. Afortunadamente para ella, la voracidad del conde se combinó con la comprensión solidaria de su hermano y de su madre que entregaron una tierra para evitar tan terrible correctivo. Con un encuadre institucional, las prácticas difíciles de erradicar, por lo menos se limitaban ${ }^{104}$.

El señor sancionaba y presionaba mediante la pérdida de tierras. No olvidaba que tenía a su disposición instrumentos más contundentes si ello era necesario. Muchas veces Sánchez Albornoz evocó a Cresconio, praepositus del monasterio de Celanova, cuando lograba que Elario le cediera sus propiedades amenazándolo con la servidumbre ${ }^{105}$. No fue un caso excepcional. Los condes de nuestra zona amenazaban con la ordalía, con un testimonio desfavorable, o con el castigo físico. Esto indica que a la presión se oponía algún grado de resistencia, sobre la que nos han quedado indicios. Su larvada realidad explica que la transformación del uso y costumbre, lejos de ser un desarrollo sereno, instituía un campo de fuerzas de muchas dimensiones. En la lucha por ese cambio se condensaba un nexo social múltiple que era al mismo tiempo político, jurídico, económico y familiar. También ético: a la moral comunitaria, conformada por una dosis

101. O de las Dueñas, doc. 96, año 1020, «pospusi eo Frenando mea muliere Leocadia que tenea indotata et inarata pro que me conmisit eo Frenando in adulterio gum Iusta, muliere qui fuit de meo germano, de Lalano».

102. Una muestra de estas reglas de comunidad está proporcionada por la comunidad de Sepúlveda. Lugar libre de la regulación condal, allí se admitía que el hombre dejara el matrimonio pero se condenaba con más rigor si era la mujer la que se separaba, norma que se explica por la frontera y la necesidad de mujeres. Ver, SÁEz, op. cit., fuero del año 1076, tit. 16, «Si aliqua mulier laxauerit uirum suum, CCC solidos pectet; et si uir laxauerit uxorem suam, uno arienzo deuitet».

103. O de las Dueñas, doc. 137a, año 1027, «Auria, encinta de su primo congermano, nomine Algastre, et fornicauit cum eo».

104. O de las Dueñas, doc. 103, pena por separarse de la mujer.

105. SÁnchez Albornoz, C., El régimen de la tierra en el reino asturleonés hace mil años, Buenos Aires 1978 , p. 35, n. 59 , «dedit nobis illas in offertione pro que querebamus eum mitere seruitiale et non erat sua uoluntate». 
equilibrada de enconos y solidaridades, se oponía como su antítesis la ética de la sujeción, del acatamiento a una autoridad indiscutible.

\section{ESQUEMA DE LAS RELACIONES SOCIALES DE PRODUCCIÓN Y SU CONEXIÓN CON PRÁCTICAS DEL PODER}

Logramos determinar que en los territorios que estaban bajo la autoridad del señor, éste establecía una serie de servicios, en un principio de carácter militar, transformados luego en obligaciones agrarias poco precisas, que terminaban por convertirse en rentas fijas cuantitativamente designadas. Esa imprecisión persistía en la villa de Regos (Villaviciosa de la Ribera) en el año 1031, cuando el rey Vermudo se la daba a Froila Muñoz (fidele nostro comite) con el derecho de inmunidad, estando sus habitantes sujetos al nuevo señor y obligados a rentas consuetudinarias no definidas ${ }^{106}$. El lacayo del conde debía pues recorrer el territorio para imponer las cargas requeridas para cada momento y para cobrar las caloñas, con lo cual la estructura de ese poder, el número de sus agentes, era de primordial importancia ${ }^{107}$. A uno de ellos, el juez, encontró Pedro en Valdoré, y a pesar de que le mostró sus credenciales, su sello, se negó a cumplir el «mandato». Fue una desobediencia muy costosa para Pedro, que debió ceder al conde unos frutales ${ }^{108}$. Es una prueba más de que las rentas se imponían gradualmente con una coerción y castigo que actuaba como factor determinante en última instancia (según la conocida expresión de Engels). Muchos ingresos del conde se debían a multas o impuestos (o la multa transfigurada en impuesto) por el uso de los montes o por otros delitos. Así es posible interpretar un documento que nos devela algunos de estos beneficios. Fernando Braoliz, que tenía a su cargo las mandaciones de Curueño, Lorma y Ferraras, adcomentatas por Pedro Flainiz, fue descubierto defraudando a su señor en una suma calculada en trescientos sueldos, por haber retenido bueyes, vacas, plata y lienzos que había recaudado ${ }^{109}$. Los bienes mencionados parecen corresponder a ese tipo de exacciones, y el agente señorial o el mismo señor tenían que recorrer las poblaciones para controlar y exigir las rentas. En sus estadías debían proveerse de los alimentos.

106. $O$ de las Dueñas, doc. 148, «et omines qui ibidem sunt abitantes uel uenerint ad abitandum ad uestram concurrant ordinationem et reddant uobis obsequium, secundum solitum abuerunt ad genitores uel ad abios nostros».

107. O de las Dueñas, estos aparecen mencionados en distintos textos. Por ejemplo, en doc. 122, el sayón; doc, 124, los vicarios, doc. 129, el juez; doc. 143, el mayordomo.

108. O de las Dueñas, doc. 57, «Et dauo eo Petru ipsa racione in ipsos pomares ad uobis Petru Flaginici per que mentiuit eo, Petru, segelo que mi mostrauit Cidi, qui est iudice, et recesei de facere ipso mandato».

109. O de las Dueñas, doc. 107, año 1021, «fecit eo Fredenando Braolizi de ipsos iudicatos menos ad uobis Petru Flainizi boues et uacas et ariento et lencius, in pretio de CCCtos solidos». 
Sin desconocer la importancia de las primitivas reciprocidades en los banquetes, de esa vigilancia mezclada con coacción habrían surgido también obligaciones estables de hospedaje ${ }^{110}$.

Vimos también que el conde se orientaba a la adquisición de tierras ${ }^{111}$. El resultado fue que las villae se convirtieron en patrimonio señorial a partir del mando territorial, pero a su vez en esos lugares el señor tenía bienes propios ${ }^{112}$. Se reproducía así la compleja superposición de derechos que los antropólogos encuentran en sus indagaciones. Esta circunstancia plantea un interrogante. Quedan sin resolver las relaciones sociales que se establecían en las tierras que pasaban a propiedad del conde. Lamentablemente, los documentos de nuestro archivo local, que corresponden a los alrededores del año mil, no nos informan al respecto $^{113}$. Debemos salir una vez más de ese ámbito circunscrito para ensayar una respuesta con distintas informaciones. Podemos considerar tres categorías de trabajadores:

La primera son los servi que se mencionan en el fuero de León, que en gran parte no pueden ser interpretados como esclavos en el sentido clásico del término, sino como campesinos instalados en tierras, como indica la norma que prohíbe que vendan sus posesiones ${ }^{144}$. Sin desconocer la importancia de los esclavos domésticos ${ }^{115}$, muchos otros fueron instalados en tierras. Esto muestra otra de las prácticas condales. La instalación de los servi en tierras, pareciera que no debe entenderse como el resultado de un examen de costos comparativos,

110. Por ejemplo, Fueros de reino de León, doc. 56, año 1198, fuero dado por la abadesa de San Pedro de las Dueñas a los pobladores de Mahudes, obligándolos a alimentar al prior con cinco de sus hombres y tres animales en su visita anual al lugar, tit. 6, «si prior fuerit semel in anno date ei et V homines et tres bestias edendum panem et uinum et carnem et ceuada». Para el cambio de reciprocidad en el banquete a tributo, ver, Barbero de Aguilera, A. y Loring García, M. I., «Del palacio a la cocina. Estudio sobre el conducho en el Fuero Viejo», en En la España Medieval, 14, 1991; DA GRACA, L., «Problemas interpretativos sobre behetrías», en Anales de Historia Antigua y Medieval, 29, 1996.

111. Los bienes del conde aparecen profusamente mencionados. En la Colección de Santa Maria de Otero de las Dueñas, vimos cómo tomó tierras por diversos procedimientos, además de las compras, los cambios etc. También son mencionados los bienes condales en Sahagún II, docs. 428, 476, 477, 497, 518, etc.

112. D. Catedral de León doc. 38, año 979, esto se ve claramente. Un poblador tenía una viña en Mahudes, villa del obispo Sisnando, y la pierde a causa de un homicidio. En Cardeña, año 963, Fronilde, de la familia del conde Fernán González, daba al monasterio una serie de «villas proprias».

113. O de las Dueñas, doc. 143, año 1029, Pedro Flaínez cambia las heredades que tiene en Lorma por otras en Velilla de Valdoré, y si bien las enumera, no habla de las relaciones de trabajo. En este texto se menciona a Felice, mayordomo.

114. Fuero de León, tit. 7, «Decreuimus iterum ut nullus emat hereditatem serui ecclesie, seu regis, uel cuiuslibet hominis»

115. SÁnchez Albornoz, C., «Los siervos en el noroeste hispano hace un milenio», en Cuadernos de Historia de España LXI-LXII. O de las Dueñas, doc. 30a, del 981-994, entre los bienes que se entregan por casamiento se mencionan «XIII inter serbos et ancillas». 
sino como una acción en correspondencia con las características globales que adquiría el sistema de producción. Es lo que trasluce el documento que relata el poblamiento de la sede de Lugo, a mediados del siglo viII, realizada bajo la dirección del obispo Odoario, que concurrió allí cum nostris multis familis, et cum ceteris populis tam nobiles quam inobiles ${ }^{116}$. Restaurado el lugar, la instalación de campesinos para que trabajen la tierra pareciera una culminación natural de su accionar: fecimus de nostra familia possessores...et dedimus illis boves ad laborandum. Otros esclavos eran también convertidos en libertos instalados en tierras ${ }^{117}$. Si bien muchos conservaron un estatuto de no libres, en la práctica se indiferenciaban en más de un aspecto con los campesinos ingenuos. De la catedral de León proviene un documento, fechado en el año 864, en el que un siervo de nombre Ausonio daba a su señor Nuño la parte de dos pomares que le correspondía entre sus hermanos ${ }^{118}$. De la misma procedencia tenemos otro texto en el cual consta que pocos años más tarde el mismo propietario recibía por profiliación de un siervo dos villae en igualdad con sus hijos que, afirma, de recto coniungio habeo ${ }^{119}$. La aclaración es significativa. Se trataba de un productor con un estatuto de no libre, pero que sin embargo estaba establecido con familia y tenía derecho a la herencia. Avalan además esta tesis menciones en documentos de diversa procedencia de no libres y casati en villae ${ }^{120}$.

La homogeneidad fáctica de la estructura social se constituía también a través de inorgánicas acciones contra los señores que instalaban una compenetración de intereses entre los distintos rangos de los subalternos. Del Tumbo

116. Floriano, A. C., Diplomática española del periodo astur. Estudio de las fuentes documentales del reino de asturias (718-910), I, Oviedo, 1949-1951 (2 vols.) p. 62. La autenticidad de este documento ha sido defendida por SÁnchez Albornoz, C., Despoblación y repoblación del valle del Duero, p. 28 y s.

117. Sobrado de los Monjes, año 1000, doc. 131, carta de ingenuidad dada por una monja, «libertis meis qui estis habitantes in comitatu Presarense».

118. D. Catedral de León, doc. 52.

119. D. Catedral de León, doc. 53.

120. Sahagún I, doc. 328, año 985, Jimena dona la villa de Salorio con «servos ibidem servientes et ancilla mea nomine Tinonia cum filiis et nepotibus suis vel omnia cognatione sua». Serrano, L., Cartulario del infantado de Covarrubias, Valladolid 1906, año 978, p. 19, «in rio de Lazeto XX kasatos». HinojosA, Documentos, p. 19, año 1041, donación de tierras»cum totis nostris mancipiis ibidem habitantibus». Cardeña, p. 316, año 981, en Poza de la Sal, «XV homines kasatos». M de la Cogolla, p. 81, año 1006, «in Ventosa undecim casatos et in Riuulosicco octo casatos». En Oña, doc. 8, el conde de Castilla fundaba en el año 1011 el monasterio, y en el otorgamiento de posesiones se mencionaban los casati, «in Uientreta septem casatos. In Cantabrana septem casatos. In Ferrera duodecim casatos (etc.)». Encontramos menciones de esta categoría más tarde, por ejemplo, en Fueros del reino de León, doc. 18, de Castrocalbón dado por la condesa María en 1152, tit. 19. Tambien, Historia Compostelana., citada, cuando se mencionan las donaciones que el conde Munio y su esposa la condesa Lupa realizaron a Santiago, se precisa: «in Salceta, unum servitialem cum sua haereditate; in Amunio, alium servitialem cum sua hereditate; in Decia, villam de Vellegio cum sua creatione» (col. 992-993) 
de Sobrado de los Monjes nos han llegado noticias del hijo de unos campesinos que estaba en libertad bajo fianza, pero fugó con un ladrón condenado y un siervo llamado Maurelo ${ }^{121}$. Del mismo archivo proviene una escritura que menciona a otro hijo de campesinos que se unía con el siervo del conde para robar $^{122}$. Los campesinos de nuestro estudio local no permanecieron ajenos a estas solidaridades con los domésticos del señor. Tenemos noticias de un condenado por haber instigado a una esclava a robar grano de la casa de Froila Muñoz $^{123}$. De esos contactos surgían vínculos afectivos que borraban los prejuicios. Así lo sintió Enego, que ayudado por su madre y por su hermano, huyó con Midona, cubileira (jurídicamente libre) de Froila Muñoz, para consumar con ella el enlace legalmente impedido por el estatus social ${ }^{124}$. Los enamorados lograron unirse, pero éste no es un cuento de hadas con un buen final. Acusado Enego de rapto, no pudieron escapar a la persecución del conde ${ }^{125}$. Junto con Midona fue reducido a la servidumbre de Froila Muñoz y su mujer, aunque con la posibilidad de obtener la libertad a la muerte de estos, salvo si se encomendaban a otro señor, con lo cual quedarían en servidumbre para siempre, comodo sunt alios serbus originalis. Vemos muchas cosas aquí: una constitución popular de la pareja no atada a las mismas convenciones que regían entre los señores; vemos la ayuda de la familia al hijo que desea una doméstica; y vemos finalmente la astucia del señor ofreciendo un futuro de libertad si renuncian a toda tentación de escapar. Pero además de las desventuras de los pobres y los explotados, este cuento nos muestra que la coacción y el intervencionismo general del conde en las sociedad empujaba a los subalternos a su fusión en una única masa social.

La segunda categoría fueron los libres que perdieron sus tierras y el señor permitía que continuaran trabajando en la tenencia pagando rentas «dominica-

121. Sobrado de los Monjes, doc. 21, «Fugiuit itaque filius noster et sacauit de uestro ligamine unum latronem nomine Tadoy qui habebat uobis a peitare IIIes kauallos de furto, et alium uestrum seruum nomine Maurelo».

122. Sobrado de los Monjes, doc. 24, año 931, «Ego Miru et uxor mea Froisenda uobis Hermegildo et uxori uestre Paterne. Non est enim dubium...quod peccato impediente fecit furtum filius noster nomine Fafila cum illo uestro seruo nomine Gaton».

123. O de las Dueñas, doc. 115 año 1022, «sua ancilla, nomini Todildi, et furtauit de sua casa quartarios VIIII de ceuaria per suasione de Emlo». También, idem, doc. 116.

124. O de las Dueñas, docs. 118 y 120, año 1022. Ese estatus no estaba constituido por la condición jurídica sino por la condición de doméstica; ver sobre la posición jurídicamente libre de esta servidora del conde, Rodríguez, J., Los fueros del reino de León, I, Estudio crítico, Madrid 1981, p. 38-40. El concepto de estatus abarca un plano más amplio que el legal

125. O de las Dueñas, doc. 118, «et fecimus ipso rapto et exierunt post me cum uoce de rapto et preserunt me cum illa». 
les» o los libres que no tenían tierras y trabajaban in solare alieno ${ }^{126}$. En el fuero de León sus rentas eran enunciadas ${ }^{127}$, y su vida era similar a la de otros productores no libres. Las diferencias de estatus empezaban a ser trascendidas por las diferencias económicas, y ello se reflejaba en la distinción que la autoridad establecía con respecto a los tributos según los medios de producción ${ }^{128}$.

Por último, no descartemos la presencia de trabajadores contratados por salario (pretium laborantium) ${ }^{129}$. Es posible que ésa fuera la condición de pastores, interpretación avalada por la relación que posteriormente iba a predominar en esta actividad ${ }^{130}$, aunque también consta la existencia de pastores en condicion de no libres ${ }^{131}$. El señor no subestimaba ningún recurso para llevar adelante su producción, y en este caso, utilizaba recursos líquidos para contratar campesinos que necesitaban complementar sus ingresos, dando por resultado una forma primitiva de proletariado que reproducía valores de consumo.

En definitiva, la práctica social múltiple del conde, regida por el precepto de transformar las relaciones sociales libres en relaciones de extracción de plus trabajo, se traducía en una creciente homogeneidad social de los subalternos. Los habitantes de la mandación podían estar sujetos a distintos impedimentos para desplazarse a voluntad ${ }^{132}$. En la medida en que estaban sometidos a tributos, se igualaban tanto a los que habían perdido sus bienes como a los servi casati. La

126. Fuero de León, tit. 25; tit. 12, menciona a los que trabajaban las heredades del rey (hereditates regis). Esta relación social perteneciente a los condes se ve en textos más tardíos, Fueros del reino de León, de Castrocalbón, doc. 18, año 1152, dado por la condesa María, tomando los preceptos del fuero de León. Heredades que pasaban al señor y seguían trabajadas por sus antiguos propietarios como tributarios, en, Sahagún II, doc. 577, año 1055, en una donación de heredades en Santa Columba realizada en 1055 para el monasterio, el donante aclaraba, «ut teneat illud filia mea Uita Domenquiz in uita sua et post obitum suum ueniat post partem Sancti Facundi; et si filios habuerit, serviant Sancti Facundi et si noluerint careant ipsa hereditate». También, idem, doc. 726, año 1073; doc. 847, de 1089; doc. 861 de 1090; doc. 862 de 1090 ; doc. 880 de 1091; doc. 896, de 1092; doc. 906 de 1093; doc. 909 de 1093; doc. 918 de 1094; doc. 930 de 1094; doc. 997 de 1097; doc. 1001 de 1097; doc. 1014 de 1097, doc. 1032 de 1098; doc. 1042 de 1099; doc. 1048 de 1100; etc. En otros, serían campesinos sin tierras o con escasas tierras que trabajaban en propiedades de los señores. En el Fuero de León, se mencionan a los iuniores sin tierras, ex capite, como cuberos o albendarios.

127. Fuero de León, 26, «Qui habuerit casam in solare alieno, et non habuerit kaballum uel asinum det semel in anno domino soli decem panes frumenti, et mediam kannatellan uini, et unum lumbum bonum»

128. Fuero de León, 25, 26, 27.

129. Fuero de León, tit. 29. Fueros del reino de León, doc. 18 del 1152.

130. O de las Dueñas, doc. 33, año 995, un campesino debía entregar un viña que tenía junto al río Tuerto, en Astorga, por haber dañado el ganado de Froila Vimáraz, quien en el año 989 había obtenido de Vermudo II la donación de una heredad en Antoñán del Valle, según consta en el doc. 23. Es posible que fuera un asalariado.

131. En D. Catedral de León, doc. 10, año 917, se mencionan dos «pueros Sarrazinus» como pastores.

132. O de las Dueñas, doc. 140 del año 1027, sentencia por irse de la mandación. Idem, doc. 148 del año 1031, los habitantes de la villa de Regos, que quedaban bajo el mando de Frolia Muñoz, podían irse, «sicut alii ingenui», pero debían dejar sus heredades para el conde, «iuri uestro, ut de eas facias quod 
misma propiedad para el habitante de un territorio se transformaba, en virtud de las obligaciones, en un derecho formal e incluso formalmente negado ${ }^{133}$.

\section{POR UNA SISTEMATIZACIÓN GENERAL}

1) La desigualdad cuantitativa entre el señor y el campesino, expresada como el crecimiento de la gran propiedad a expensas del pequeño propietario, no es más que un aspecto secundario que se desprende de un desarrollo esencialmente cualitativo. El proceso se expresa como el pasaje de la articulación política entre un centro de poder y una producción campesina «alodial», en un estadio tomado como inicial, a la posterior articulación del modo de producción feudal. El ejercicio del poder fue un factor clave de esa modificación. En este sentido, el análisis nos aproximó a un rasgo central de la tesis «mutacionista» en la misma medida en que nos alejó del mecanicismo patrimonial.

2) El señorío no surgió por la mera violencia ni tampoco por imposiciones repentinas de «malas» costumbres en un plácido escenario donde regía el orden público. El poder político, en un principio general y laxo, se constituyó en poder de control y sujeción campesina en un devenir secular. El fundamento sociológico de ello está en que el conde observaba un comportamiento constructivo de la relación social, actuando sobre la costumbre para transformarla, y simultáneamente conservarla de manera parcial. Como diría un hegeliano profesor de filosofía, el sujeto aquí «media» (vermittelt) y «supera» (aufhebet) la negatividad. El conde se apoyaba en una racionalidad campesina con la que se comprometía, y con esa base, permutaba trabajo destinado a la reproducción doméstica del productor directo en trabajo excedente para su consumo progresivamente señorial. Preservaba el recurso de producción, y su autoridad se realizaba como poder político sin negarse como poder de función. Todo el proceso se condensaba en la modificación paulatina de las costumbres. En este sentido, nos hemos alejado del mutacionismo.

3) Tampoco se constata una ruptura uniforme de las relaciones sociales. Cada localidad constituía una columna de evolución propia ${ }^{134}$, y la tendencia sólo

tua extiterit uoluntas». En ciertos casos, esto se regía por encomendación personal, por ejemplo, en idem, doc. 124.

133. Alfonso $V$, doc. 7, año 1009 , en el derecho dado al monasterio de Celanova de someter a los habitantes de Val de Iglesia, se dice, «concedimus cum omnia quod possident». Idem, año 1010, doc. 8, en una donación al monasterio de San Miguel de Bárcena, el rey donaba «homines de mea mandatione cum suis hereditatibus, et mando quod faciant tale obsequium ecclesie Sancti Micaelis quale faciebant aliis regibus meis antecessoribus».

134. Cfr. Freedman, P., «La servidumbre catalana y el problema de la Revolución feudal», en Hispania 193, 
se establece como un valor social promedio. Este carácter no sincrónico del cambio, a pesar de una evolución integral uniforme, deriva de la naturaleza individual con que se establecía cada soberanía jurisdiccional, de la forma personalizada de cada construcción práctica de poder a través de una práctica razonada y razonablemente constructiva, modificada por las condiciones objetivas en las que se daba. Ello se tradujo en desarrollos geográficamente limitados de cada poder individualizando una forma social.

4) El proceso que se describió en este estudio no proporciona un relato de conjunto de la construcción de las relaciones sociales de producción en el feudalismo. Para no mencionar más que una de las tantas cuestiones dejadas de lado, recordemos que la iglesia, con su poder espiritual, plantea problemas propios. Sólo nos limitamos aquí a examinar el proceso desde la perspectiva de las prácticas del poder condal tomadas en un sentido puro. Pero la totalidad no se comprende aquí por algo más y algo distinto a la noción enciclopédica. No se trata sólo de haber dejado de lado otras praxis como las que llevaron a las donaciones pro anima. El problema está en otro plano. Lo que se intentó dilucidar en este artículo, la praxis estructurante del poder político, no equivale a la objetividad estructural; la lógica del todo no emerge por sumatoria de las lógicas individuales; la organización general de la sociedad no es la simple trasposición de conductas. Alertar sobre los límites del artículo remite a las limitaciones del concepto liberal y expone, en contraposición la complejidad tan particular (y difícil) del marxismo ortodoxo. Si esta contribución tiene algún logro, éste se encuentra en una iluminación parcial de procesos parciales.

5) En el reino asturleonés, la comunidad, con el conjunto de sus atributos institucionales, se implementará con posterioridad al 1100 junto a la definitiva organización de la clase de poder y la regularización de la renta. Con ello adquiría una nueva forma la relación social entre señores y campesinos, mediada por la organización propia de la comunidad. Las prácticas del señor cambiarán de manera concomitante. Éste se apoyará sobre esa institución para lograr su objetivo de vivir del trabajo ajeno. Su poder de función, imprescindible para entender el proceso de la formación de las clases, estaba en vías de concluir, y se sumegirá, de manera creciente, en las cuestiones propias del estamento.

1998, p. 432, «lo que no puede admitirse es la reducción de todo a un único momento histórico y la insistencia en que en todas partes esto representó un trastorno que alteró completamente el modo de producción». 